\title{
Lactoferrin perturbs lipid rafts and requires integrity of Pma1 p-lipid rafts association to exert its antifungal activity against Saccharomyces cerevisiae
}

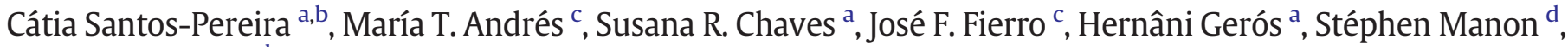 \\ Lígia R. Rodrigues $^{\mathrm{b}}$, Manuela Côrte-Real ${ }^{\mathrm{a}, *}$ \\ a Centre of Molecular and Environmental Biology (CBMA), Department of Biology, University of Minho, 4710-057 Braga, Portugal \\ ${ }^{\mathrm{b}}$ Centre of Biological Engineering (CEB), Department of Biological Engineering, University of Minho, 4710-057 Braga, Portugal

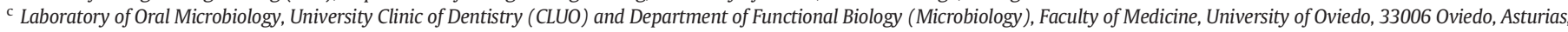 \\ Spain \\ d Institut de Biochimie et de Génétique Cellulaires, UMR5095, CNRS et Université de Bordeaux, CS61390, 1 Rue Camille Saint-Saëns, 33000 Bordeaux, France
}

\section{A R T I C L E I N F O}

\section{Article history:}

Received 26 November 2020

Received in revised form 30 December 2020

Accepted 31 December 2020

Available online 07 January 2021

\section{Keywords:}

Lactoferrin

Yeast cell death

Lipid rafts

Pma1p

V-ATPase

\begin{abstract}
A B S T R A C T
Lactoferrin (Lf) is a bioactive milk-derived protein with remarkable wide-spectrum antifungal activity. To deepen our understanding of the molecular mechanisms underlying Lf cytotoxicity, the role of plasma membrane ergosterol- and sphingolipid-rich lipid rafts and their association with the proton pump Pma1p was explored. Pma1p was previously identified as a Lf-binding protein. Results showed that bovine Lf (bLf) perturbs ergosterol-rich lipid rafts organization by inducing intracellular accumulation of ergosterol. Using yeast mutant strains lacking lipid rafts-associated proteins or enzymes involved in the synthesis of ergosterol and sphingolipids, we found that perturbations in the composition of these membrane domains increase resistance to bLf-induced yeast cell death. Also, when Pma1p-lipid rafts association is compromised in the Pma1-10 mutant and in the absence of the Pma1p-binding protein Ast1p, the bLf killing activity is impaired. Altogether, results showed that the perturbation of lipid rafts and the inhibition of both Pma1p and V-ATPase activities mediate the antifungal activity of bLf. Since it is suggested that the combination of conventional antifungals with lipid rafts-disrupting compounds is a powerful antifungal approach, our data will help to pave the way for the use of bLf alone or in combination for the treatment/eradication of clinically and agronomically relevant yeast pathogens/fungi.
\end{abstract}

(C) 2021 Elsevier B.V. All rights reserved.

\section{Introduction}

Lactoferrin (Lf), a glycoprotein with ca. $80 \mathrm{kDa}$, is one of the most well-known milk bioactive proteins. Besides in milk, it is present in many different biological fluids of mammalian species including mucosal surfaces, saliva and tears [1]. Multiple biological activities have been attributed to this protein since it was first identified in bovine milk more than 80 years ago [2], such as anticancer and antimicrobial [3], including antifungal activity against different species of both yeasts and molds.

The mechanisms underlying the Lf antifungal activity described so far generally rely on its ability to sequester iron, to interact with the cell surface and to induce cell death [4]. In fact, we previously found that human $\mathrm{Lf}(\mathrm{hLf})$ induces an apoptotic-like cell death process in the

* Corresponding author at: Department of Biology, University of Minho, Campus de Gualtar, 4710-057, Braga, Portugal.

E-mail address: mcortereal@bio.uminho.pt (M. Côrte-Real). yeasts Candida albicans [5] and Saccharomyces cerevisiae [6], which is associated with nuclear chromatin condensation, increased production of reactive oxygen species and mitochondrial dysfunctions. Furthermore, we identified the plasma membrane proton pump Pma1p as a hLfbinding protein [7]. Pma1p is a P-type $\mathrm{H}^{+}$-ATPase that mediates proton extrusion powered by ATP hydrolysis to maintain $\mathrm{pH}$ homeostasis, ion balance and nutrient uptake in plant cells and fungi [8]. By binding and inhibiting Pma1p activity, hLf leads to increased intracellular ATP levels, perturbation of cytosolic $\mathrm{pH}$ and ion homeostasis and, consequently, lethal mitochondrial dysfunction [7,9].

Pma1p is localized at specific nanodomains of the plasma membrane called lipid rafts $[10,11]$. These are highly organized and tightly packed structures rich in ergosterol and sphingolipids that function as platforms for signalling and protein trafficking. They are generally identified as detergent-resistant membranes (DRMs) after cell fractioning with non-ionic detergents [11]. Lipid rafts affect the mechanical properties of the plasma membrane and are involved in fungal pathogenicity and biofilm formation [65]. Moreover, since lipid rafts are involved in the 
delivery of proteins to membranes such as multidrug resistance pumps, they have been implicated in drug resistance. Several antifungal peptides can target lipid rafts, affecting their integrity and the function of these pumps, which allows them to overcome drug resistance and to induce cell death $[13,14]$. Thus, the combination of antifungal peptides targeting lipid rafts with conventional antifungal drugs has been suggested as a powerful antifungal strategy [15].

Different reports have supported the importance of lipid rafts for Pma1p activity. Indeed, lipid raft association is crucial for proper surface targeting and Pma1p stability at the plasma membrane [16]. Thus, disruption of lipid rafts leads to mistargeting of Pma1p to the vacuole [17]. Sphingolipids, which are critical and abundant in lipid rafts, are also required for Pma1p oligomerization at the ER, its targeting to the plasma membrane, and its stability at the cell surface $[18,19]$.

Given this interplay and interdependence between Pma1p and lipid rafts, and because Lf binds and inhibits this proton pump, in the present study we aimed to uncover the role of lipid rafts in bovine Lf (bLf)-induced cell death, and to explore the bLf-Pma1p-lipid rafts axis. Human and bovine Lfs share a high degree of sequence identity (69\%) [20], a similar structure [21] and function/activity against fungi [22]. The effect of lipid raft composition on bLf cytotoxicity was studied using yeast mutant strains lacking lipid rafts-associated proteins or enzymes that mediate the synthesis of ergosterol and sphingolipids, the major components of DRMs. The Rvs161p (encoded by RVS161/END6 gene) is a protein localized in lipid rafts [23]. The ERG6 gene encodes the sterol C-24 methyltransferase that catalyses the final steps of ergosterol biosynthesis by converting zymosterol to fecosterol (Fig. 1A). Therefore, erg6 $\Delta$ mutants accumulate mainly zymosterol and cholesta-5,7,24trienol instead of ergosterol [24]. The other two genes under study are involved in the sphingolipid metabolism (Fig. 1B). LAC1 encodes a component of ceramide synthase, which is involved in de novo synthesis of ceramide by $\mathrm{N}$-acylation of sphingoid bases. The ISC1 gene encodes the mitochondrial inositol phosphosphingolipid phospholipase $C$ that is involved in the synthesis of ceramide by hydrolysis of complex sphingolipids (Fig. 1B) [25].

\section{Materials and methods}

\subsection{Strains and plasmids}

All S. cerevisiae strains and plasmids used in this study are listed in Table 1. BY4741 and L3852 were used as wild type strains. BY4741, $\operatorname{erg} 6 \Delta, r v s 161 \Delta$, lac $1 \Delta$, isc $1 \Delta$ and ast $1 \Delta$ strains were transformed with the pRS316 Pma1-GFP using the LiAc/SS Carrier DNA/PEG method [26]. The ast $1 \Delta$ strain was transformed with the high copy pAC49 AST1 plasmid using the same method. The XGY32 strain harbours the pma1-10 mutations and it was produced by pop-in pop-out gene replacement of the PMA1 gene [16].

\subsection{Growth conditions}

All strains were grown in YEPD (yeast extract-peptone-dextrose) medium [ $1 \%(w / v)$ yeast extract, $2 \%(w / v)$ peptone, $2 \%(w / v)$ glucose], with the exception of the strains expressing plasmids that were grown in Synthetic Complete Glucose medium [SC Glu pH 5.5; 2\% ( $w / v)$ glucose; $0.67 \%(w / v)$ yeast nitrogen base without amino acids and ammonium sulphate; $0.5 \%(w / v)$ ammonium sulphate; $0.1 \%(w / v)$ potassium phosphate, $0.2 \%(w / v)$ drop-out mixture lacking histidine, leucine, tryptophan and uracil; $0.01 \%(w / v)$ histidine, $0.02 \%(w / v)$ leucine and $0.01 \%$ $(w / v)$ tryptophan]. The yeast strains were grown at $30{ }^{\circ} \mathrm{C}$ in an orbital shaker at $200 \mathrm{rpm}$, with a ratio of flask volume/medium of $5: 1$ until reaching the exponential phase $(\mathrm{OD} 640=0.6-0.8)$.

\subsection{Lactoferrin treatment and cell survival assays}

After reaching the exponential phase, yeast cells were harvested, resuspended in $10 \mathrm{mM}$ Tris-HCl buffer $\mathrm{pH} 7.4$ [6] and incubated with 0-1500 $\mu \mathrm{g} / \mathrm{ml}$ bLf and/or with $20 \mu \mathrm{M}$ C2-ceramide (N-Acetyl-D-sphingosine, Sigma-Aldrich) or its solvent (absolute ethanol) for $90 \mathrm{~min}$ under the same aforementioned growth conditions (and/or at $37{ }^{\circ} \mathrm{C}$ in

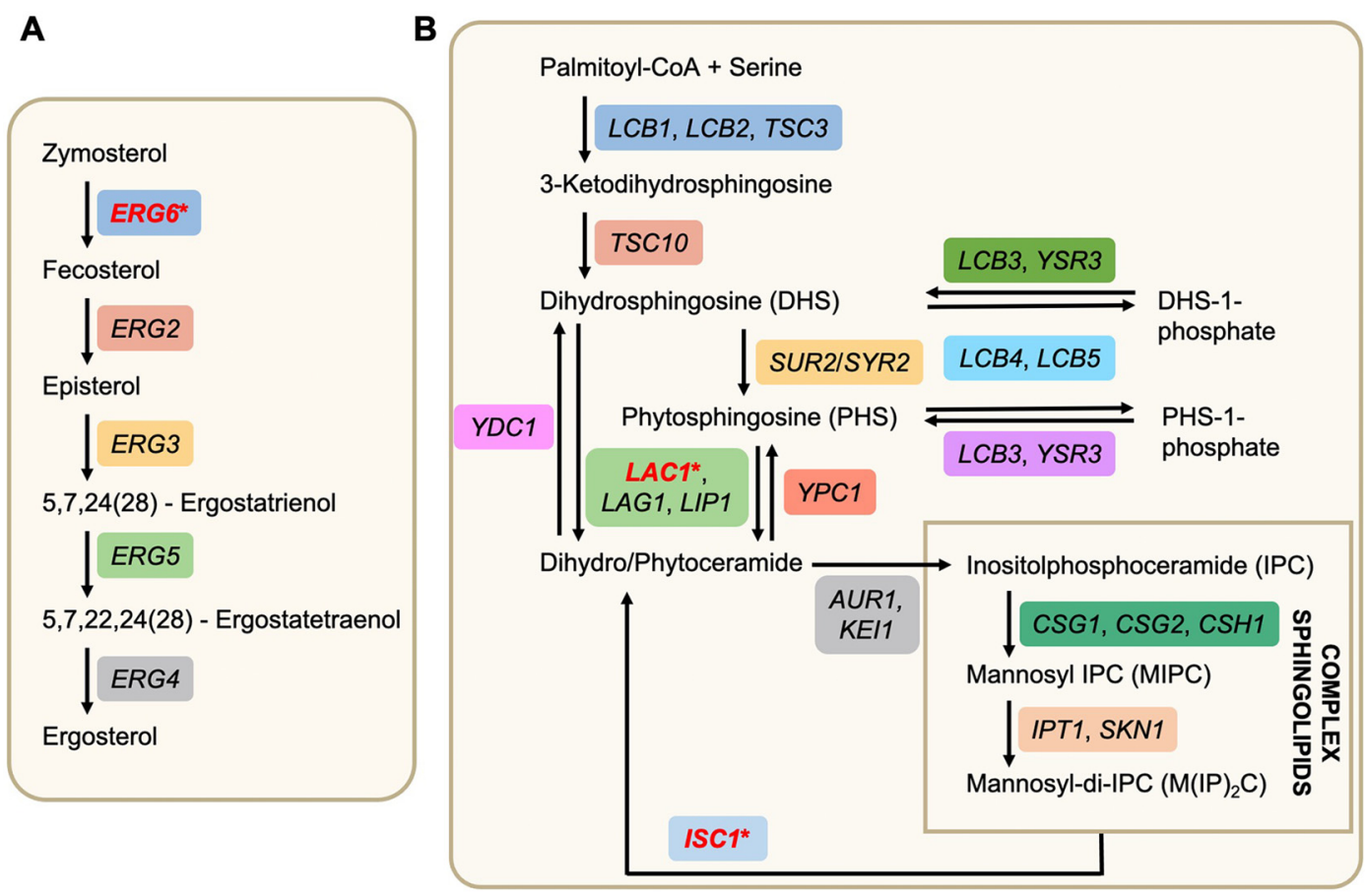

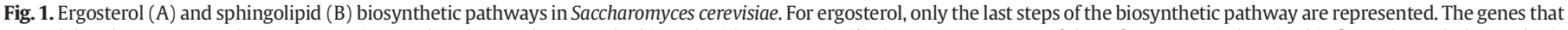

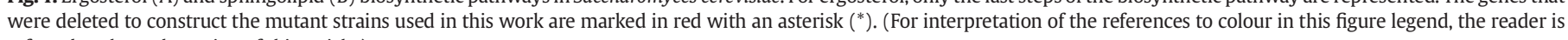
referred to the web version of this article.) 
Table 1

List of S. cerevisiae strains and plasmids used.

\begin{tabular}{|c|c|c|}
\hline Strain & Genotype & Reference/source \\
\hline BY4741 & MATa his $3 \Delta 1$ leu $2 \Delta 0$ met $15 \Delta 0$ ura $3 \Delta 0$ & Euroscarf \\
\hline $\operatorname{erg} 6 \Delta$ & $\begin{array}{l}\text { MATa his } 3 \Delta 1 \text { leu } 2 \Delta 0 \text { met } 15 \Delta 0 \text { ura } 3 \Delta 0 \\
\text { erg6 } \Delta:: \text { KanMX4 }\end{array}$ & Euroscarf \\
\hline 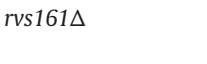 & $\begin{array}{l}\text { MATa his } 3 \Delta 1 \text { leu } 2 \Delta 0 \text { met } 15 \Delta 0 \text { ura } 3 \Delta 0 \\
\text { rvs } 161 \Delta:: \text { KanMX } 4\end{array}$ & Euroscarf \\
\hline $\operatorname{lac} 1 \Delta$ & $\begin{array}{l}\text { MATa his } 3 \Delta 1 \text { leu } 2 \Delta 0 \text { met } 15 \Delta 0 \text { ura } 3 \Delta 0 \\
\text { lac1 } \Delta:: K a n M X 4\end{array}$ & Euroscarf \\
\hline$i s c 1 \Delta$ & $\begin{array}{l}\text { MATa his } 3 \Delta 1 \text { leu } 2 \Delta 0 \text { met } 15 \Delta 0 \text { ura } 3 \Delta 0 \\
\text { isc } 1 \Delta:: \text { KanMX } 4\end{array}$ & Euroscarf \\
\hline ast1 $\Delta$ & $\begin{array}{l}\text { MATa his } 3 \Delta 1 \text { leu } 2 \Delta 0 \text { met } 15 \Delta 0 \text { ura } 3 \Delta 0 \\
\text { ast } 1 \Delta:: K a n M X 4\end{array}$ & Euroscarf \\
\hline BY4741 PMA1-GFP & BY4741 harbouring pRS316 PMA1-GFP & This study \\
\hline $\operatorname{erg} 6 \triangle \mathrm{PMA1-GFP}$ & erg6 $\Delta$ harbouring pRS316 PMA1-GFP & This study \\
\hline$r v s 161 \Delta$ PMA1-GFP & $\begin{array}{l}\text { rvs } 161 \Delta \text { harbouring pRS316 } \\
\text { PMA1-GFP }\end{array}$ & This study \\
\hline lac1 $\triangle$ PMA1-GFP & lac1 $\Delta$ harbouring pRS316 PMA1-GFP & This study \\
\hline isc1 $\triangle$ PMA1-GFP & isc1 $1 \Delta$ harbouring pRS316 PMA1-GFP & This study \\
\hline ast1 $\triangle$ PMA1-GFP & ast $1 \Delta$ harbouring pRS316 PMA1-GFP & This study \\
\hline ast1 $\triangle \mathrm{AST} 1$ & ast1 $\Delta$ harbouring pAC49-AST1 & This study \\
\hline L3852 & $\begin{array}{l}\text { MATa his } 3 \Delta 200 \text { lys } 2 \Delta 201 \text { leu2-3112 } \\
\text { ura3-52 ade2 }\end{array}$ & [43] \\
\hline XGY32 & $\begin{array}{l}\text { MAT } \alpha \text { his } 3 \Delta 200 \text { lys } 2 \Delta 201 \text { leu2-3112 } \\
\text { ura3-52 ade2 pma1-10 }\end{array}$ & [16] \\
\hline Plasmid & Description & Reference \\
\hline pRS316 PMA1-GFP & $\begin{array}{l}\text { PMA1 gene fused with the yeast GFP3 } \\
\text { gene, URA3 }\end{array}$ & [23] \\
\hline pAC49-AST1 & AST1 URA3 $2 \mu$ & [43] \\
\hline
\end{tabular}

the case of L3852 and XGY32 strains). Lower incubation times were employed in the experiments with isolated plasma membranes (15 min) and vacuoles (right before ATP addition) as well as with bLfFITC (75 min). bLf was obtained from DMV (Veghel, The Netherlands). The protein is ca. $80 \%$ pure, with $3.5 \%$ moisture, and $21 \%$ ironsaturated, according to the manufacturer. bLf was dissolved in sterile distilled water $\left(\mathrm{dH}_{2} \mathrm{O}\right)$ to obtain the different concentrations used throughout this work.

Cell survival was evaluated by counting of colony forming units (c.f. u.). Briefly, four serial dilutions of the cultures were performed, and the $10^{-4}$ dilution was plated onto YEPD containing $2 \%(w / v)$ agar and incubated for $48 \mathrm{~h}$ at $30^{\circ} \mathrm{C}$. The percentage of cell survival was calculated from the number of c.f.u. of each condition in relation to time zero and the control without any treatment.

\subsection{Filipin staining, PMA1-GFP localization and fluorescence microscopy}

For visualization of sterol-rich lipid rafts, yeast cells were stained with filipin (Filipin III from Streptomyces filipinensis, Sigma), a naturally fluorescent antibiotic widely used to visualize sterols [27]. After treatment with or without bLf, cells were collected at an OD640 $=0.5$ and concentrated $20 \times$ in sterile water. Immediately before visualization under the fluorescence microscope, cells were incubated for $1 \mathrm{~min}$ in the dark with $0.1 \mathrm{mg} / \mathrm{ml}$ filipin from a stock solution of $5 \mathrm{mg} / \mathrm{ml}(w / v)$ in methanol [28]. Cells were then mounted on slides with the antifading agent Vectashield (Vector Laboratories) to overcome the instability of this dye, and then visualized in an epifluorescence microscope. As a positive control of lipid rafts disruption, cells were treated for $30 \mathrm{~min}$ at $30{ }^{\circ} \mathrm{C}$ in an orbital shaker at $200 \mathrm{rpm}$ with $5 \mathrm{mg} / \mathrm{ml}$ methyl- $\beta$-cyclodextrin $(\mathrm{M} \beta \mathrm{CD})$ in $10 \mathrm{mM}$ Tris-HCl buffer $\mathrm{pH}$ 7.4.

For determination of Pma1p localization, PMA1-GFP expressing cells without any treatment were grown until early-exponential phase, collected by centrifugation at $3000 \times \mathrm{g}$ for $3 \mathrm{~min}$, and resuspended in sterile water at an OD640 $=10$. Samples were observed under the fluorescence microscope immediately. The percentage of cells with altered Pma1p localization was calculated by counting the number of cells with normal and altered Pma1p localization in each observed field. More than 800 cells were counted.
The images were obtained in the fluorescence microscope (Leica DM 5000B, Leica Microsystems) with appropriate filter settings using a $100 \times$ oil-immersion objective with a Leica DCF350FX digital camera, and processed with LAS Leica Microsystems software.

\subsection{Lactoferrin-FITC labelling}

For labelling of bLf with fluorescein-5-isothiocyanate (FITC), $50 \mu \mathrm{g} /$ $\mathrm{ml}$ of FITC (Sigma-Aldrich) were added to a solution of $18,13 \mathrm{mg} / \mathrm{ml}$ of bLf in $1 \mathrm{M}$ sodium bicarbonate buffer $\mathrm{pH}=9$ and incubated for $2 \mathrm{~h}$ in the dark with agitation. Afterwards, the unbound FITC was removed by several spin-separation cycles at $6000 \times g$ for 5 min using Amicon Ultra-0.5, Ultracel-30 Membrane (30 kDa cutoff), and finally buffer exchange to water was performed using the same approach. A control with only FITC was performed and added to cells. No fluorescence was detected using the same settings as those for bLf-FITC.

\subsection{Assessment of metabolic activity by FUN-1 staining}

Metabolic activity of yeast cells was evaluated by Fun-1 [(2-chloro4-(2,3-dihydro-3-methyl-(benzo-1,3-thiazol-2-yl)-methylidene)-1phenylquinolinium Iodide), Molecular Probes] staining. Fun-1 is a membrane-permeant dye that is transported to the vacuole and compacted into cylindrical intravacuolar structures (CIVS) only in metabolically active yeast cells [29]. After $90 \mathrm{~min}$ incubation in the absence or presence of $425 \mu \mathrm{g} / \mathrm{ml} \mathrm{bLf}, 1 \mathrm{ml}$ of cells at OD640 $=0.1$ were harvested, resuspended in phosphate buffered saline (PBS) $1 \times$ (PBS 10×; $137 \mathrm{mM} \mathrm{NaCl}, 2.7 \mathrm{mM} \mathrm{KCl}, 10 \mathrm{mM} \mathrm{Na}_{2} \mathrm{HPO}_{4}, 1.8 \mathrm{mM} \mathrm{KH}_{2} \mathrm{PO}_{4}, \mathrm{pH} 7$ ) and stained with $4 \mu \mathrm{M}$ FUN- 1 for $30 \mathrm{~min}$ at $30^{\circ} \mathrm{C}$ in the dark. 5 minboiled wild type cells were used as a positive control for defective metabolic activity. Stained cell suspensions were then analysed in an epifluorescence microscope and in a flow cytometer. Flow cytometry data are presented as the mean FL4 fluorescence intensity in relation to the autofluorescence of each sample and untreated cells of each strain.

\subsection{Analysis of glucose-dependent extracellular acidification}

Extracellular acidification rate was estimated as previously described [7]. Briefly, after growth and treatment without or with $0-1500 \mu \mathrm{g} / \mathrm{ml}$ bLf or $100 \mu \mathrm{M}$ diethylstilbestrol (DES) as reported for cell survival assays, cells were washed once with $50 \mathrm{mM} \mathrm{KCl}$ and then resuspended and concentrated $\left(10^{7}\right.$ cells $\left./ \mathrm{ml}\right)$ in $1 \mathrm{ml}$ of $50 \mathrm{mM} \mathrm{KCl}$ and subjected to $\mathrm{pH}$ measurements. After $\mathrm{pH}$ stabilization, $2.5 \mathrm{mM}$ glucose was added and acidification was measured every minute for 12 min using a pH meter with constant stirring. A sample was taken from each condition to estimate the dry weight after incubation at $80{ }^{\circ} \mathrm{C}$ for two days. Data is presented as $\Delta \mathrm{pH} / \mathrm{min} / \mathrm{mg}$ dry weight.

\subsection{Plasma membrane isolation}

Plasma membranes were obtained as described previously [7], with some modifications. Briefly, 41 of yeast culture were grown in YEPD medium until late-log phase. Cells were then harvested, washed twice with distilled sterile water and resuspended in homogenization buffer [ $2 \mathrm{mM}$ EDTA, 2\% ( $w / v)$ glucose, $1 \mathrm{mM}$ phenylmethylsulfonyl fluoride (PMSF), $0.2 \mathrm{ng} / \mathrm{ml}$ DNase, $50 \mathrm{mM}$ Tris $\mathrm{pH}$ 7.4]. Whole cells were then disrupted by three passages at $19,500 \mathrm{lb} . / \mathrm{in}^{2}$ in a French pressure cell (SLM Aminco, Silver Spring, MD). The resulting cell suspension was centrifuged at $3000 \times \mathrm{g} 4{ }^{\circ} \mathrm{C}$ for 10 min to remove cell debris and unbroken cells, and the supernatant was centrifuged twice at $14000 \times g 4^{\circ} \mathrm{C}$ for $30 \mathrm{~min}$. Afterwards, the homogenate was centrifuged at $100000 \times \mathrm{g}$ $4{ }^{\circ} \mathrm{C}$ for $1 \mathrm{~h} 30 \mathrm{~min}$ and the pellet containing the cell membranes was resuspended in ice-cold resuspension buffer [0.5 mM EDTA, 20\% $(\mathrm{v} / \mathrm{v})$ glycerol, $0.1 \mathrm{mM}$ PMSF, $10 \mathrm{mM}$ Tris $\mathrm{pH}=7.4]$. Protein concentration 
was estimated by Bradford assay [30] before storage of samples at $-80{ }^{\circ} \mathrm{C}$.

\subsection{Measurement of ATP hydrolysis}

ATP hydrolysis assay was performed using the PiColorLock ${ }^{\mathrm{TM}}$ Gold Phosphate Detection kit (obtained from Innova Biosciences, Ltd. Cambridge, UK), which allows the quantification of the inorganic phosphate (Pi) concentration, according to the manufacturer's instructions. For all experiments, a calibration curve with a standard range of Pi concentrations was performed. Measurements were performed in isolated plasma membranes at a concentration of $12.5 \mu \mathrm{g} / \mathrm{ml}$ in assay medium containing $0.2 \mathrm{mM}$ ATP. To avoid interference of the activity of vacuolar and mitochondrial ATPases and acid phosphatases, membranes were preincubated for $15 \mathrm{~min}$ at $30{ }^{\circ} \mathrm{C}$ with $50 \mathrm{mM} \mathrm{KNO}_{3}, 0.2 \mathrm{mM}$ ammonium molybdate and $5 \mathrm{mM}$ sodium azide [31], respectively. Afterwards, membrane extracts were incubated with $100 \mu \mathrm{g} / \mathrm{ml}$ bLf or $100 \mu \mathrm{M}$ DES for 15 min at $30^{\circ} \mathrm{C}$. DES was used as a positive control for Pma1p inhibition [7]. Pi concentration was calculated by spectrophotometry at $620 \mathrm{~nm}$.

\subsection{Evaluation of intracellular ATP concentration}

Intracellular ATP concentration was quantified using the BacTiterGlo $^{\mathrm{TM}}$ Microbial Cell Viability kit as recommended. For all experiments, a calibration curve with standard ATP concentrations (10-1000 nM) was performed. Cells were grown as described for cell survival assays and treated in the absence or presence of 250 and $425 \mu \mathrm{g} / \mathrm{ml} \mathrm{bLf}$ and $100 \mu \mathrm{M}$ DES for $90 \mathrm{~min}$ at $30{ }^{\circ} \mathrm{C}$ with $200 \mathrm{rpm}$ agitation. $50 \mu \mathrm{l}$ of each condition were transferred to a 96-well opaque plate, mixed with equal volume of BacTiter-Glo reagent and incubated for $15 \mathrm{~min}$ in the dark. The emitted luminescence was read in a Varioskan flash multimode reader (Thermo Scientific). The reagent uses a thermostable luciferase that produces a luminescence signal proportional to the ATP concentration. Data is shown in arbitrary units as fold change expressed in relation to the untreated control of each strain (considered as 1).

\subsection{Protein extraction and Western blot}

For preparation of whole cell extracts, $1 \mathrm{ml}$ of exponentially growing cells at $\mathrm{OD} 640=1$ were harvested by centrifugation at $5000 \times \mathrm{g}$ for 3 min and washed once with $\mathrm{dH}_{2} \mathrm{O}$. Cells were then resuspended in $500 \mu \mathrm{l}$ water containing $50 \mu \mathrm{l}$ lysis buffer $3.5 \%(v / v) \quad \beta$ mercaptoethanol in $2 \mathrm{M} \mathrm{NaOH}$ ) and incubated for $15 \mathrm{~min}$ on ice. Next, $50 \mu \mathrm{l}$ of $50 \%$ trichloroacetic acid were added and incubated for additional $15 \mathrm{~min}$ to precipitate the proteins. The extracts were centrifuged at $10000 \times \mathrm{g} 10 \mathrm{~min} 4^{\circ} \mathrm{C}$, washed with acetone and centrifuged again. Finally, protein extracts were resuspended in Laemmli buffer $(2 \%(v / v) \beta$ mercaptoethanol, 0.1 M Tris pH 8.8, 20\% ( $v / v)$ glycerol, 0.02\% $(v / v)$ bromophenol blue). Samples were heated at $95{ }^{\circ} \mathrm{C}$ and used immediately for Western blot or stored at $-20^{\circ} \mathrm{C}$.

For detection of Pma1p expression levels, $50 \mu \mathrm{g}$ of protein extracts were separated by $10 \%$ sodium dodecyl sulfate - polyacrylamide gel electrophoresis (SDS-PAGE) for $1 \mathrm{~h}$. Proteins were then transferred onto nitrocellulose membranes and membranes were blocked in $5 \%$ non-fat milk in PBS-Tween $0.1 \%(v / v)$ solution $(1 \times$ PBST) with agitation at RT for $1 \mathrm{~h}$ to avoid non-specific interactions. Membranes were then cut into strips and incubated overnight at $4{ }^{\circ} \mathrm{C}$ with the primary antibodies mouse monoclonal anti-yeast phosphoglycerate kinase (Pgk1p) antibody (1:5000, Molecular Probes) and mouse monoclonal antibody to Pma1p (1:1000, 40B7, Invitrogen). Pgk1p was used as the loading control. Subsequently, membranes were incubated with the secondary antibody Peroxidase-AffiniPure goat anti-mouse IgG (1:5000, Jackson ImmunoResearch). Chemiluminescence detection was performed using the ECL detection system (Millipore-Merck) in a ChemiDoc XRS system (Bio-Rad).

\subsection{Isolation of intact yeast vacuoles}

Vacuole isolation was performed as previously described [32,33]. After grown until an OD640 $=0.7,11$ of BY4741 cell suspension was collected, washed twice with ice-cold distilled water, resuspended in washing buffer [5\% $(w / v)$ glucose, $10 \mathrm{mM}$ MES (morpholineethanesulfonic acid)-Tris, $\mathrm{pH}$ 6.5] and incubated in a shaker at $30^{\circ} \mathrm{C}$ for $30 \mathrm{~min}$. Afterwards, cells were incubated with digestion buffer [1.35 M sorbitol, $10 \mathrm{mM}$ citric acid, $30 \mathrm{mM} \mathrm{Na}_{2} \mathrm{HPO}_{4}, 1 \mathrm{mM}$ EGTA (ethylene glycol-bis( $\beta$-aminoethyl ether)-N,N,N $\mathrm{N}^{\prime}, \mathrm{N}^{\prime}$-tetraacetic acid), $30 \mathrm{mM}$ DTT (dithiothreitol), pH 7.5] for $15 \mathrm{~min}$ at room temperature. Spheroplasts were generated by subsequent incubation with $2 \mathrm{mg} / \mathrm{mL}$ of zymolyase in digestion buffer without DTT, and cell wall digestion was monitored in a phase contrast microscope. When digestion was completed, spheroplasts were pelleted by centrifugation at $2750 \times \mathrm{g}$ for $5 \mathrm{~min}$ and washed with digestion buffer without DTT. They were then resuspended in $12 \%(w / v)$ Ficoll and homogenized in a PotterElvehjem to disrupt the cell membrane. To isolate vacuoles by Ficoll gradient centrifugation, the resulting homogenate was centrifuged at $2750 \times g$ for $3 \mathrm{~min}$ and the supernatant was recovered. The gradient was prepared by carefully adding $8 \%(w / v)$ Ficoll on the top of the supernatant. Ultracentrifugation was performed at $80000 \times \mathrm{g}$ for $30 \mathrm{~min}$ in a SW 28 Ti swinging-bucket rotor. The white fraction on top of the gradient containing highly purified vacuoles was collected and used in the spectrofluorometric studies. Protein concentration was determined by the Lowry method [34], using BSA ( $5 \mu \mathrm{g} / \mu \mathrm{l}-25 \mu \mathrm{g} / \mu \mathrm{l})$ to build the standard curve.

\subsection{Measurement of V-ATPase activity by spectrofluorimetry}

The pH-sensitive probe ACMA (9-amino-6-chloro-2methoxyacridine) was used to determine the proton-pumping activity of V-ATPase in the isolated vacuoles using a Perkin-Elmer LS-5B spectrofluorimeter as previously reported [32,33,35]. $20 \mu$ g of isolated vacuoles were added to a buffer containing $1 \mathrm{mM}$ MOPS [3-(N-morpholino) propanesulfonic acid]-Tris pH 7.2, $2 \mu \mathrm{M}$ ACMA, $1 \mathrm{mM} \mathrm{MgCl}_{2}$ and $100 \mathrm{mM} \mathrm{KCl} .4$ or $80 \mu \mathrm{g} / \mathrm{ml}$ bLf were added to the assay medium at steady-state to study their inhibitory effects. The reaction was started by adding $0.1-0.5 \mathrm{mM}$ ATP and the rate of initial fluorescence quenching was recorded. The excitation/emission wavelengths were set to $415 \mathrm{~nm}$ and $485 \mathrm{~nm}$, respectively. The initial rate of ACMA fluorescence quenching was considered a measure of the V-ATPase proton pumping activity $\left[\Delta \% \mathrm{~F} \mathrm{~min}^{-1}\right]$ and the fluorescence quenching recovery as the inhibition of this activity. The results were analysed using the GraphPad Prism Software and the proton pumping-kinetics best fitting the experimental initial acidification curves, corresponding to the quenching of ACMA fluorescence, were determined.

\subsection{Analysis of vacuolar $p H$ variations using the carboxy-DCFDA probe}

Vacuolar $\mathrm{pH}$ alterations were detected by both fluorescence microscopy and flow cytometry using the 5-(and-6)-carboxy-2',7'dichlorofluorescein diacetate (CDCFDA) probe. Untreated or bLftreated cells were harvested by centrifugation $(1 \mathrm{~mL} \mathrm{OD640}=0.1$ ), washed once with sterile water and resuspended in CF buffer [50 mM glycine, $10 \mathrm{mM} \mathrm{NaCl}, 5 \mathrm{mM} \mathrm{KCl}, 1 \mathrm{mM} \mathrm{MgCl}$, $40 \mathrm{mM}$ Tris, $100 \mathrm{mM}$ MES pH 4.5 supplemented with $2 \%(w / v)$ glucose] [36]. The cell suspension was then incubated with $1.6 \mu \mathrm{M}$ CDCFDA for $20 \mathrm{~min}$ at $30^{\circ} \mathrm{C}$ with $200 \mathrm{rpm}$ orbital agitation. Afterwards, cells were washed once with CF buffer without glucose, and finally resuspended in the same buffer for further analysis in the flow cytometer or fluorescence microscope. Flow cytometry data are presented as the mean FL1 fluorescence intensity in relation to the autofluorescence of each sample and untreated cells of each strain. 


\subsection{Immunoprecipitation}

For immunoprecipitation, $10 \mathrm{ml}$ of yeast culture at OD640 $=1$ were collected and resuspended in a buffer containing 2 mM EGTA, $10 \mathrm{mM}$ Tris/Maleate pH 6.8 and a cocktail of protease inhibitors (cOmplete, Roche). Mechanic lysis was then performed using glass beads and a fast prep equipment, and supernatant was collected and centrifuged at $800 \times \mathrm{g}$ for $10 \mathrm{~min} .1 \mathrm{mg}$ from the supernatant were solubilized in $1 \times$ IP50 buffer (Sigma-Aldrich) $40 \mathrm{~min}$ at $4{ }^{\circ} \mathrm{C}$ and incubated overnight with $1 \mu \mathrm{g}$ of anti-Pma1 (40B7, Invitrogen) or anti-bLf (ab112968, Abcam) antibodies. Protein G-sepharose beads (Sigma-Aldrich) were then added and incubated for additional $4 \mathrm{~h}$. Beads were washed 4 times with $1 \times$ IP50 buffer and two times with $0.1 \times$ IP50 buffer, and ressuspended in $25 \mu \mathrm{l}$ of Laemmli buffer $1 \times$, before SDS-PAGE and Western blotting.

\subsection{Flow cytometry}

Flow cytometry analysis was performed with an Epics ${ }^{\circledR}$ XLTM (Beckman Coulter) flow cytometer equipped with an argon-ion laser emitting a $488 \mathrm{~nm}$ beam at $15 \mathrm{~mW}$. Green fluorescence (CDCFDA) was collected through a $488 \mathrm{~nm}$ blocking filter, a $550 \mathrm{~nm}$ long-pass dichroic and a $525 \mathrm{~nm}$ band-pass filter. Red fluorescence (FUN-1) was collected through a $560 \mathrm{~nm}$ short-pass dichroic, a $640 \mathrm{~nm}$ long-pass, and another $670 \mathrm{~nm}$ long-pass filter. For each sample, 30,000 events were evaluated. Data were analysed using the Flowjo software.

\subsection{Statistical analysis}

Data are expressed as the mean and standard deviation values of at least three independent experiments. Statistical analyses were carried out using the GraphPad Prism software, one-way or two-way ANOVA and the Tukey post-test. $P$-values lower than 0.05 were considered to represent a significant difference.

\section{Results}

3.1. bLf induces intracellular accumulation of ergosterol perturbing lipid rafts of yeast cells

To ascertain whether ergosterol-rich lipid rafts play a role in Lfinduced cytotoxicity in yeast, their cellular distribution was assessed. Since sterols are major lipid rafts components, cellular ergosterol localization was monitored using filipin staining after $90 \mathrm{~min}$ exposure to $250-425 \mu \mathrm{g} / \mathrm{ml}$ of bLf, which induces loss of cell viability of $70 \%-98 \%$, respectively (Fig. 2A). As shown in Fig. 2B, the characteristic punctuated pattern of the lipid rafts at the plasma membrane (head arrows) is observed in control cells, while intracellular spots of filipin staining (arrows) are visible in bLf-treated cells. Cell treatment with methyl- $\beta$-cyclodextrin $(\mathrm{M} \beta C D)$, a sterol chelator known to disrupt lipid rafts by depleting ergosterol from membranes [37], induced a similar intracellular filipin-staining pattern as bLf, confirming that bLf perturbs the normal ergosterol-rich lipid rafts distribution pattern by causing intracellular accumulation of ergosterol.

3.2. Yeast mutants lacking lipid rafts-associated proteins or enzymes involved in the synthesis of the lipid rafts major components are more resistant to bLf-induced cytotoxicity

We next assessed the impact of perturbing lipid rafts composition using yeast mutants lacking proteins that are either present at lipid rafts or are involved in pathways that lead to the synthesis of their major lipid components, ergosterol and sphingolipids, namely $r v s 161 \Delta$, erg $6 \Delta$, lac1 $\Delta$ and isc $1 \Delta$ mutants (see Introduction section). Results showed that absence of these proteins greatly increases the resistance of the mutant cells to bLf-induced cytotoxicity in comparison with the wild type strain (Fig. 3A). Remarkably, even at $500 \mu \mathrm{g} / \mathrm{ml} \mathrm{bLf,} \mathrm{which}$ is highly toxic for the wild type strain (only about $2 \%$ cell survival), the mutants affected in sphingolipid metabolism exhibit about $23 \%$ of cell survival.

Our data further indicates that the metabolic activity of the wild type strain is affected by the bLf treatment using FUN-1 staining (Fig. 3B, C). FUN-1 is a membrane-permeant dye that is first detected as diffuse green fluorescence in the cytosol before its accumulation in the vacuole of metabolically active yeast cells forming red cylindrical intravacuolar structures (CIVS), as observed in Fig. 3B (red spots) [38]. The treatment of yeast cells with bLf produced a diffuse bright fluorescence, suggesting that the cells became metabolically inactive (Fig. 3B) as they were not able to process the dye at the vacuole, much like heat-killed cells [29,39]. Accordingly, flow cytometry analysis of wild type cells stained with FUN-1 showed that the red mean fluorescence intensity increased 2-fold from control to bLf-treated cells, while no differences in fluorescence intensity were observed in the mutant strains (Fig. 3C), in agreement with their higher resistance to bLf.

3.3. bLf does not alter localization of ergosterol-rich lipid rafts in rvs161ム, erg6 6 , lac $1 \Delta$ and isc $1 \Delta$ mutants

As the cytotoxicity of bLf in the wild type strain was associated with intracellular accumulation of ergosterol and perturbation of lipid rafts, the mutants under study were stained with filipin in the presence and absence of bLf. Results showed that bLf only affected ergosterol distribution in the wild type strain, showing no effect on the mutants, which is in agreement with their higher survival rate upon treatment with bLf (Fig. 4A, B).

\subsection{Inhibition of Pma1p proton pumping and hydrolytic activities by bLf is prevented in rvs $161 \Delta$, erg6 6 , lac1 $\Delta$ and isc $1 \Delta$ mutants}

We next sought to test the hypothesis that the higher resistance of the mutants is due to the lack of sensitivity of their Pma1p to bLf inhibition. As shown in Fig. 5A, the Pma1p of wild type cells was inhibited by bLf in a time- and concentration-dependent manner, much like it was previously observed in the pathogenic yeast $C$. albicans [7]. Diethylstilbestrol (DES) was used as a positive control of Pma1p inhibition [7]. When wild type cells were incubated with fluorescein-5-isothiocyanate (FITC)-labelled bLf, a punctuated pattern was observed at the plasma membrane (Fig. 5B), suggesting that bLf binds to Pma1p, as further confirmed by immunoprecipitation (Fig. 5F). Contrarily to the result obtained in the wild type cells, bLf failed to inhibit Pma1p proton pumping activity of the mutant strains $r v s 161 \Delta, \operatorname{erg} 6 \Delta, \operatorname{lac} 1 \Delta$ and isc $1 \Delta$, as indicated by the unperturbed extracellular acidification rates (Fig. 5C). Accordingly, when the hydrolytic activity of Pma1p was measured, the inhibitory effect of bLf over Pi release was much less pronounced in plasma membrane fractions isolated from the mutant strains than from wild type cells (Fig. 5D). In agreement, incubation of intact cells with bLf led to an increase in intracellular accumulation of ATP in the wild type strain but not in the mutant strains (Fig. 5E). Immunoprecipitation experiments revealed that, although Pma1p activity is not affected by bLf in the mutant strains, bLf is still able to bind the proton pump (Fig. 5F, G).

To determine whether these phenotypes could be related to intrinsic differences in Pma1p activity/localization in the mutant strains under study, all strains were transformed with a pRS316 PMA1MA-GFP plasmid and stained with filipin to visualize lipid rafts. Fluorescence microscopy showed that PMA1MA-GFP co-localizes at the plasma membrane with lipid rafts in all strains (Fig. 6A). Additionally, immunodetection of Pma1p by Western blot demonstrated that the expression levels of this proton pump are similar in all strains (Fig. 6B, C). Moreover, Pma1p activity of the mutant strains, expressed by the extracellular acidification rate, is similar to the wild type thus demonstrating that Pma1p is functional (Fig. 6D). 
A

BY 4741 wt

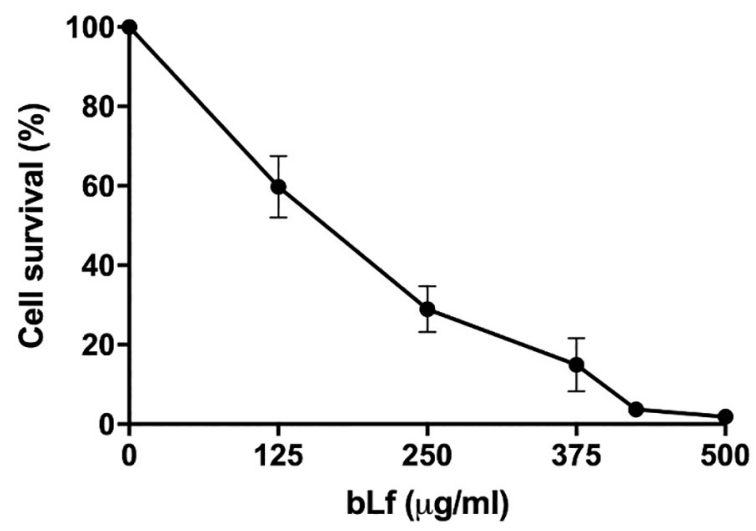

B
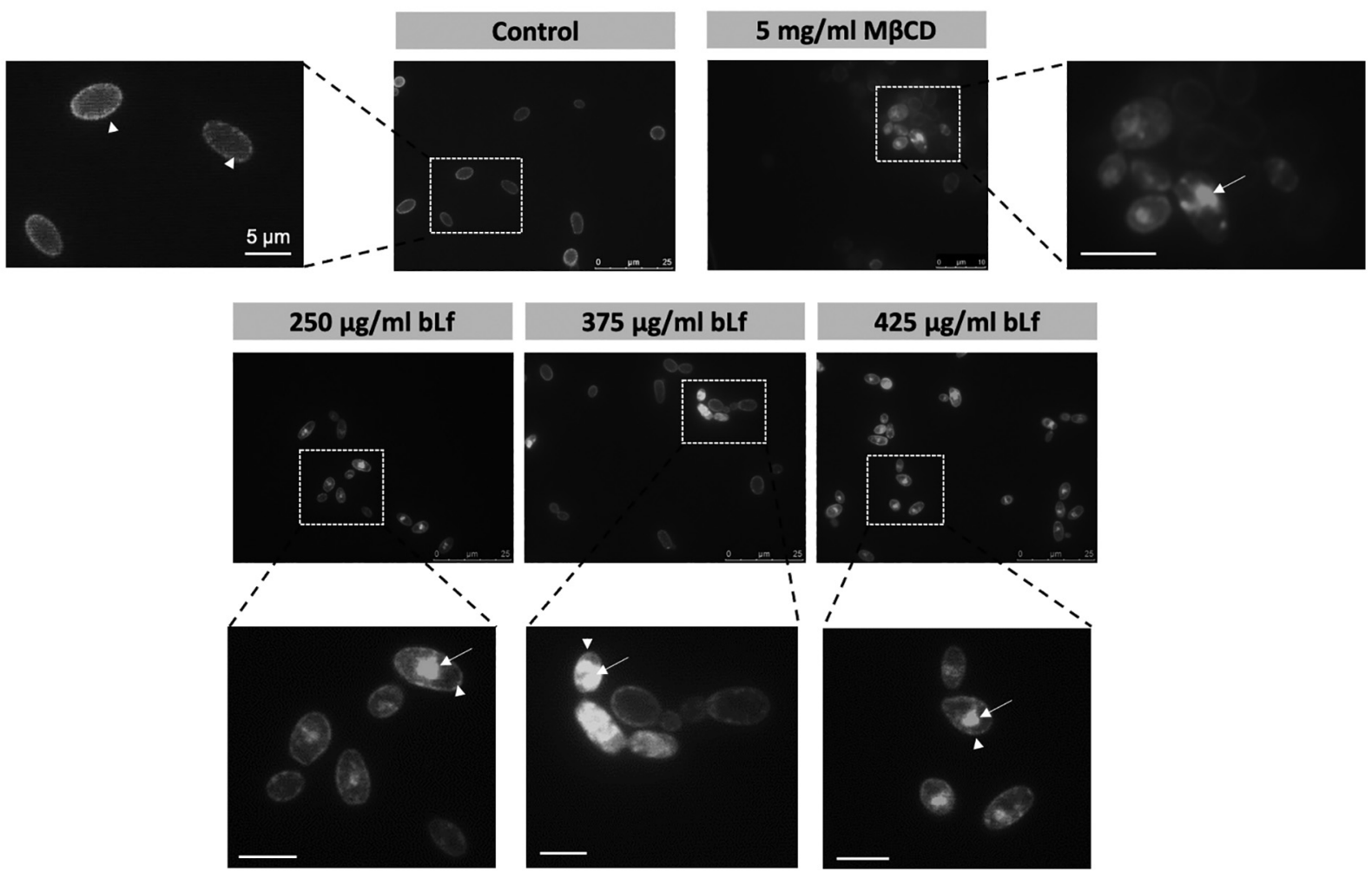

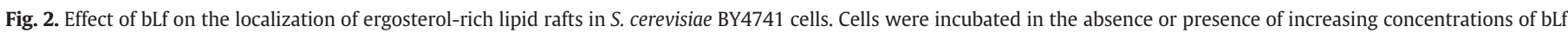

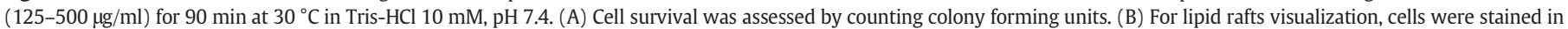

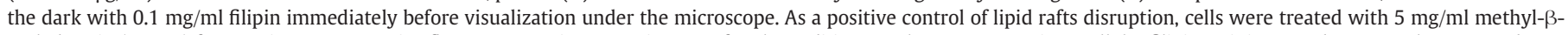

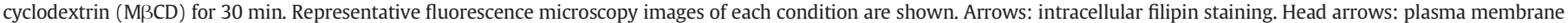
filipin staining. Bar: $5 \mu \mathrm{m}$.

3.5. bLf-induced vacuolar $p H$ perturbations are prevented in rvs161 erg6 $\Delta$, lac $1 \Delta$ and isc $1 \Delta$ mutants

Given that bLf inhibits Pma1p activity likely perturbing the intracellular $\mathrm{pH}$ homeostasis, we sought to test its effect on the vacuolar $\mathrm{pH}$. The pH-sensitive probe 5-(and-6)-carboxy-2,7-dichlorofluorescein diacetate (CDCFDA) is cleaved by intracellular esterases, and the unsterified $\mathrm{pH}$-sensitive form (CDCF) accumulates in the yeast vacuole exhibiting higher fluorescence at higher $\mathrm{pH}$ values [36,41]. Results showed that when wild type yeast cells were labelled with this $\mathrm{pH}-$ sensitive probe a higher fluorescence signal was observed in bLftreated than in untreated cells by both fluorescence microscopy (Fig. 7A, white arrows) and flow cytometry (Fig. 7B). On contrary, bLf did not induce vacuolar alkalinisation in the mutant cells (Fig. 7B).
Following our previous reports showing that bLf targets and inhibits V-ATPase activity in cancer cells [35,42], the present results suggest that V-ATPase can be inhibited by bLf in wild type yeast cells but not in mutant cells. Accordingly, results depicted in Fig. 7C showed for the first time that bLf inhibits the yeast V-ATPase proton pumping activity in a concentration-dependent manner in purified vacuolar fractions isolated from the wild type strain.

3.6. Disruption of Pma1p-lipid rafts association induced by Pma1p point mutations or AST1 deletion renders yeast cells resistant to bLf

To get further insights on the role of Pma1p localization at the lipid rafts for bLf-induced cytotoxicity, we next explored the effect of bLf on a strain harbouring Pma1p point mutations that alter its localization 
A

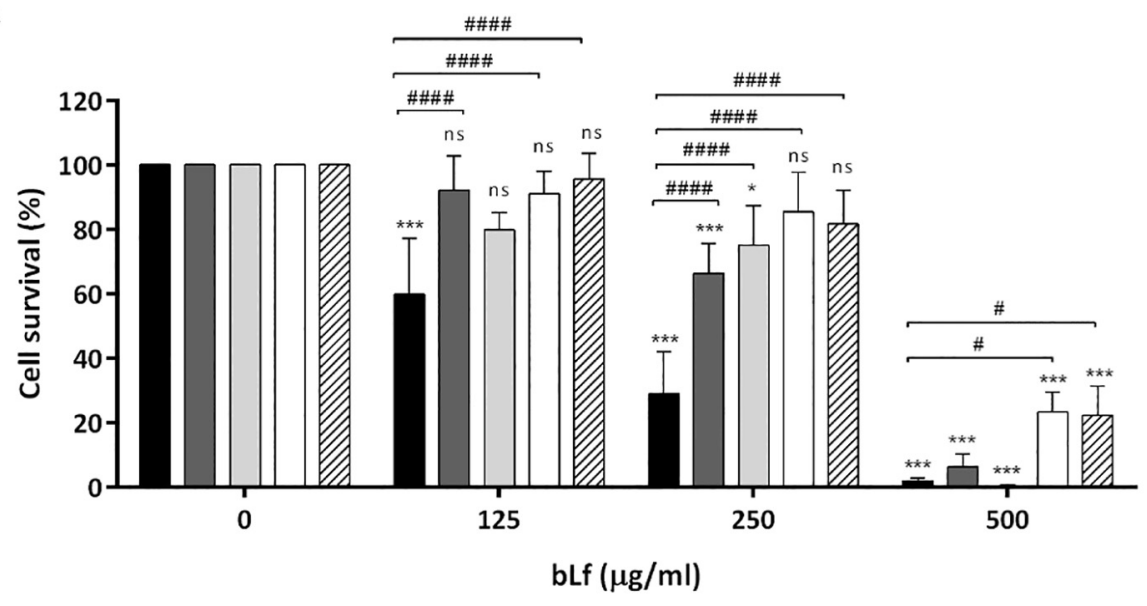

BY 4741 wt $\square$ rvs161 $\square$ erg6 $\square$ lac1s $\square$ isc1

$\mathbf{B}$

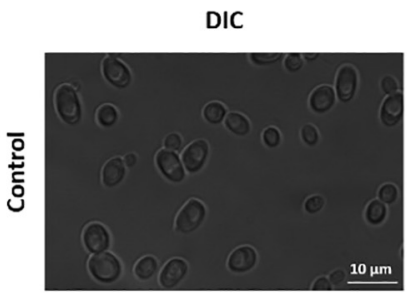

FUN-1 red fluorescence

FUN-1 green fluorescence
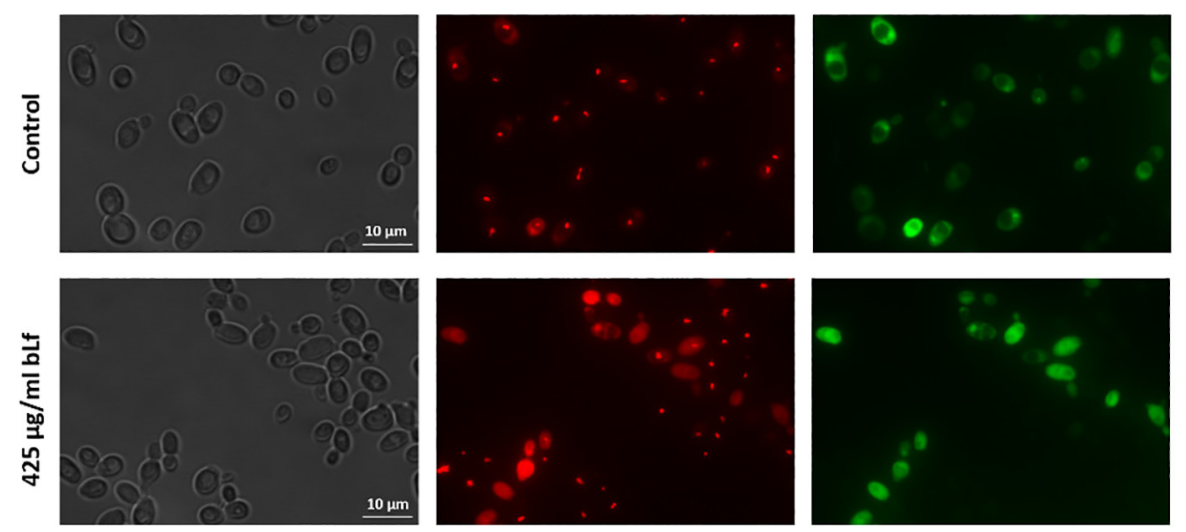

C

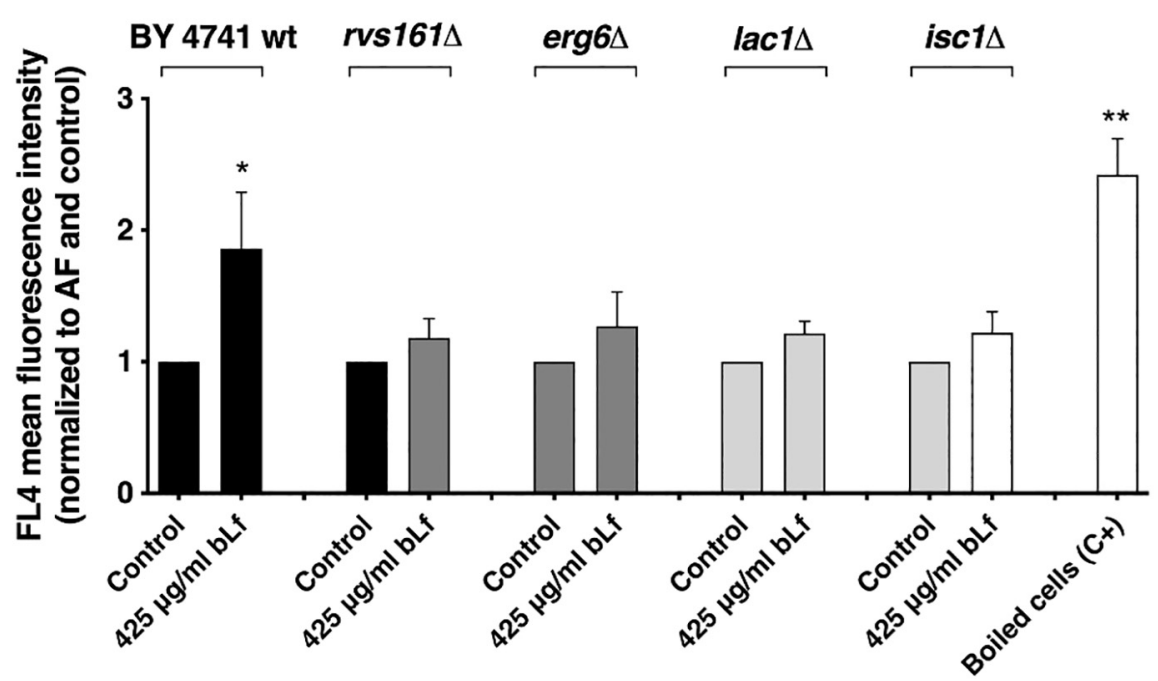

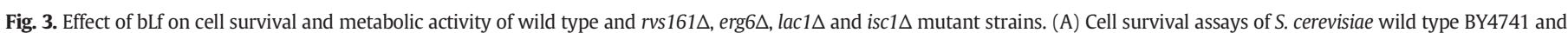

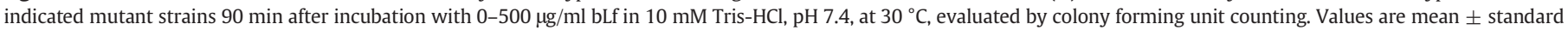

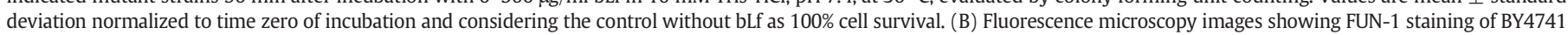

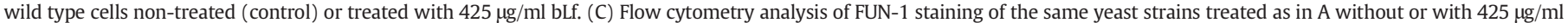

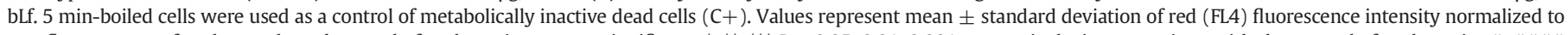

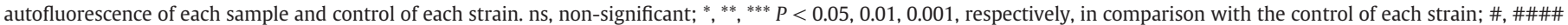

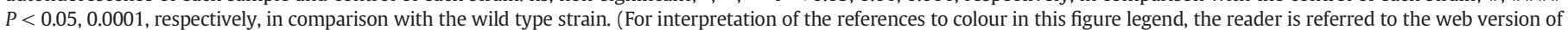
this article.) 

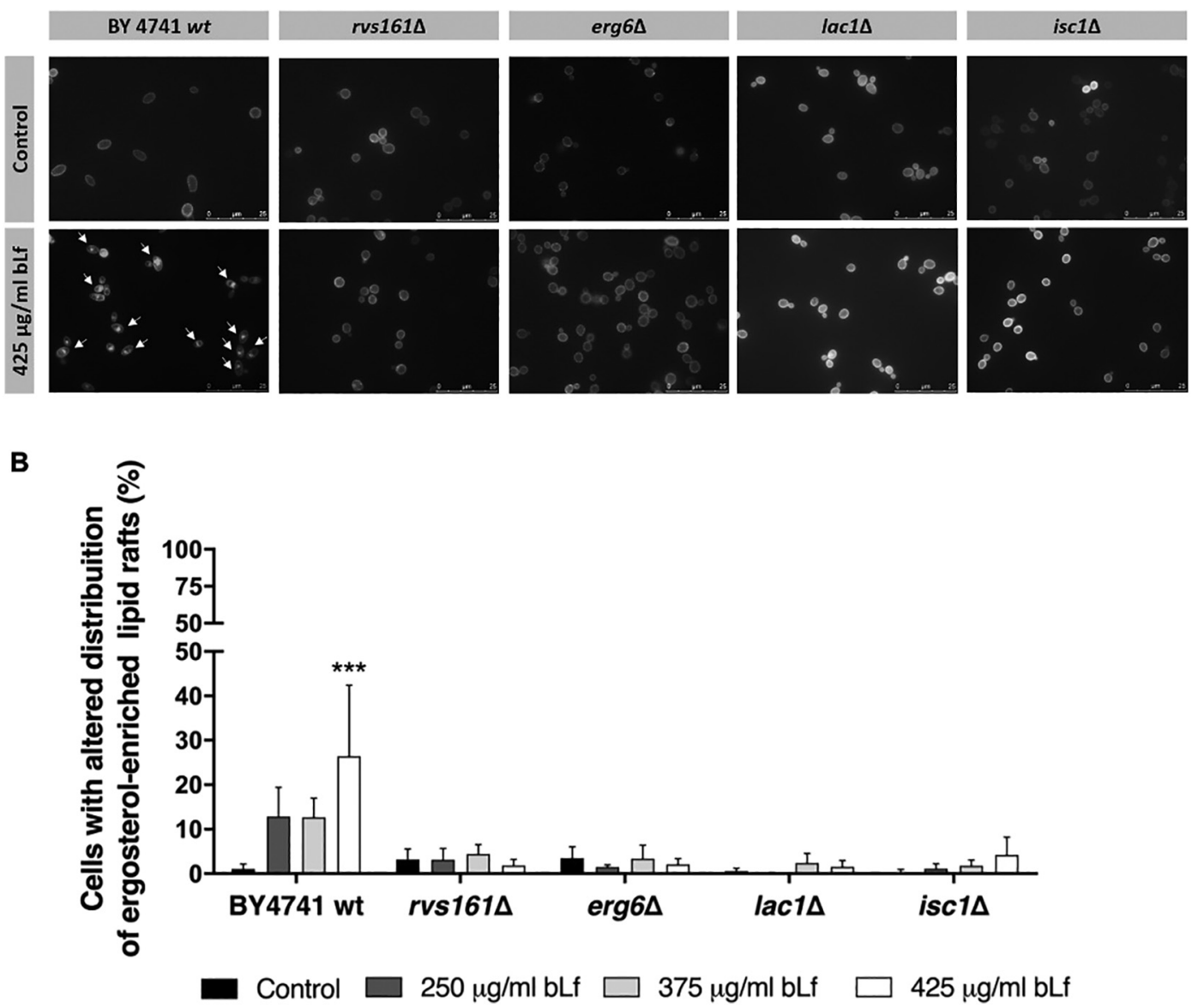

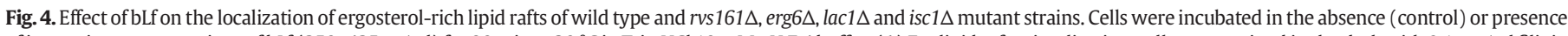

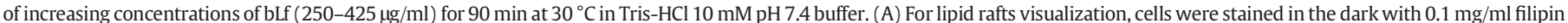

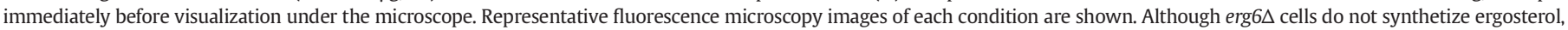

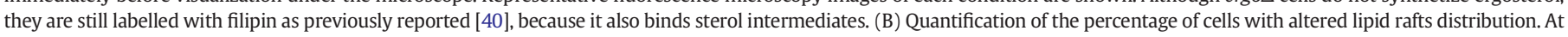
least 300 cells per condition of three independent experiments were counted. ${ }^{* * *} P<0.001$ in comparison with the control of each strain.

and association with lipid rafts. Pma1-10 (XGY32 strain) harbours the A165G and V197I mutations, both at the first cytoplasmic loop between transmembrane segments 2 and 3 of Pma1p. In this mutant strain, at the restrictive temperature of $37^{\circ} \mathrm{C}$, newly synthesized Pma1-10 fails to associate with the plasma membrane lipid rafts (Triton-insoluble fraction) and is delivered to the vacuole for degradation [16]. Results from cell survival assays showed that the Pma1-10 expressing cells are more resistant to $75 \mu \mathrm{g} / \mathrm{ml}$ bLf at both $30^{\circ} \mathrm{C}$ and $37{ }^{\circ} \mathrm{C}$ than the L3852 wild type strain, but the difference is more evident at $37{ }^{\circ} \mathrm{C}$ (Fig. 8A). In this experiment, a lower bLf concentration was used because the wild type strain is more sensitive to bLf than the BY4741 strain.

Ast1p is a Pma1p-binding protein known to be involved in the delivery of Pma1p to the cell surface and its association with lipid rafts. When multicopy AST1 is expressed in mutated Pma1p cells, Pma1p is rerouted to the cell surface and associates with lipid rafts $[17,43]$. Results showed that the deletion of AST1 gene renders cells more resistant to bLf, suggesting that its function in promoting the association of Pma1p with lipid rafts is critical for the bLf cytotoxicity (Fig. 8B). Accordingly, when multicopy AST1 is expressed in this background, cells become sensitive to bLf again, thus demonstrating that the resistance is indeed related with AST1 deletion, and not with other possible pleiotropic effects (Fig. 8B). When PMA1-GFP was expressed in ast1 $\Delta$ cells, about $30 \%$ of the cells exhibited bright intracellular spots of PMA1-GFP (Fig. 8C, D), proposing an abnormal Pma1p localization in this strain.
In agreement with the previous results, the absence of Ast $1 \mathrm{p}$ causes an abnormal intracellular localization of both ergosterol-rich lipid rafts and PMA1-GFP (Fig. 8E), which is consistent with the role of Ast1p in Pma1p-lipid rafts association.

\section{Discussion}

It has been reported that the milk-derived protein Lf displays antifungal activity against different yeast species [44], including C. albicans [5] and S. cerevisiae [6], as well as against different fungi isolated from plants and soils, including Aspergillus niger and Rhizoctonia solani [45]. Given its potential to become a wide-spectrum antifungal, herein we sought to deepen our understanding of the mechanisms underlying $\mathrm{Lf}$ cytotoxic activity using S. cerevisiae as a model. As previously shown in C. albicans [7,9], we found that bLf binds to Pma1p and inhibits its proton pumping and hydrolytic activities associated with an increase of the intracellular ATP levels. Because lipid rafts are important for cell surface sorting, stability and oligomerization of Pma1p [17], we investigated the effect of bLf in these ergosterol- and sphingolipid-rich membrane microdomains. Our data revealed a novel mode of action of bLf against yeast by inducing intracellular accumulation of ergosterol and perturbing ergosterol-rich lipid rafts. This mechanism of action is shared with edelfosine, a compound that, like lactoferrin, exhibits anticancer activity $[35,42,46]$ and a marked activity against yeast [6,46]. Indeed, it 
A

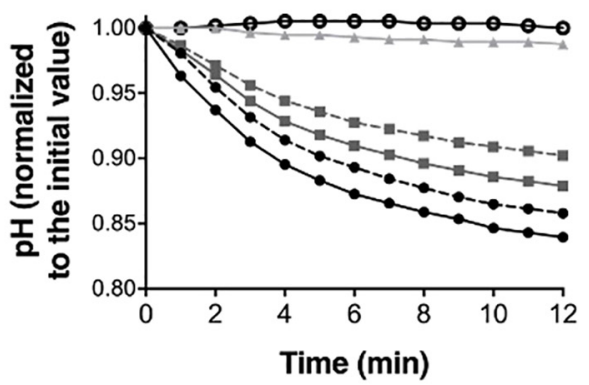

B
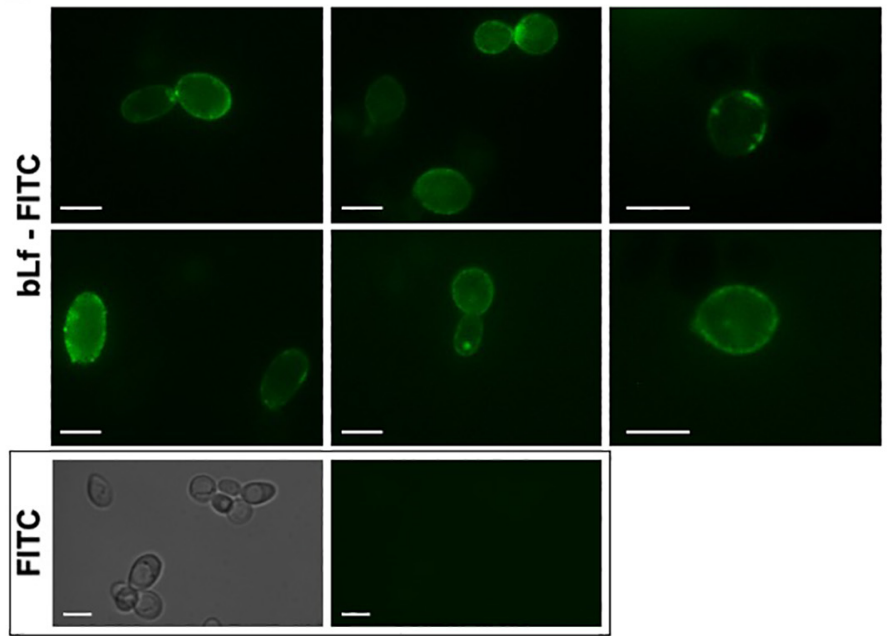

Bar: $5 \mu \mathrm{m}$

C

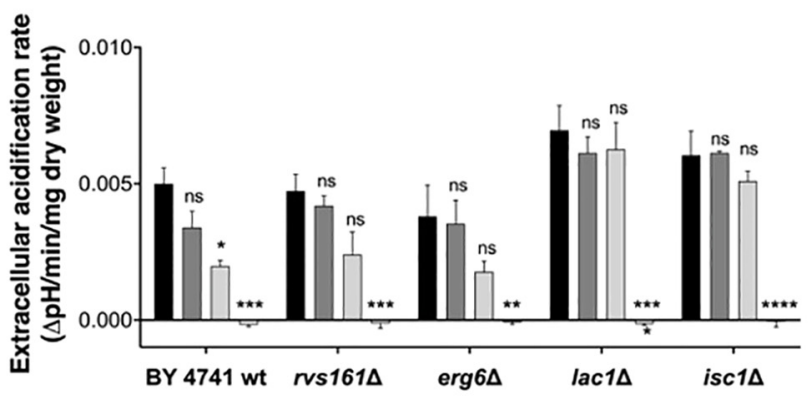

Control $\square 425 \mu \mathrm{g} / \mathrm{ml}$ bLf $\square 850 \mu \mathrm{g} / \mathrm{ml}$ bLf $\square 100 \mu \mathrm{M}$ DES
D

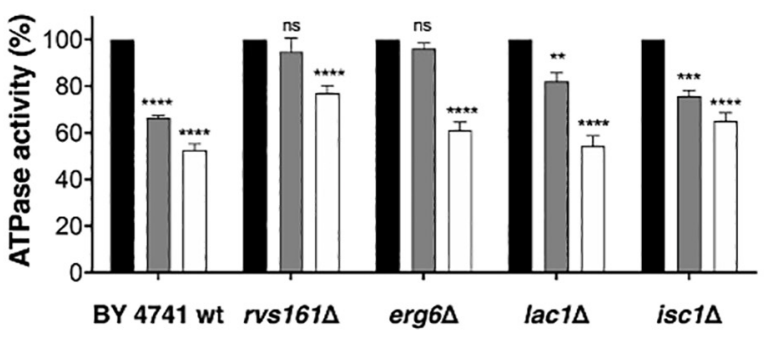

Control $\square 100 \mu \mathrm{g} / \mathrm{ml}$ bLf $\square 100 \mu \mathrm{M}$ DES

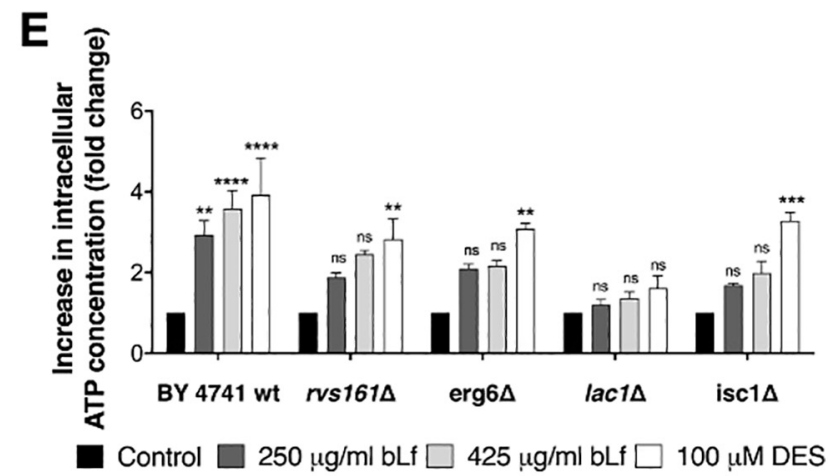

$\mathbf{F}$

IP: bLf

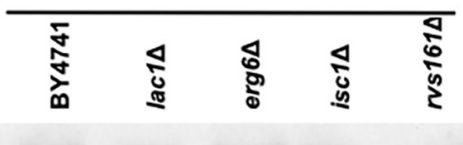

WB:Pma1p

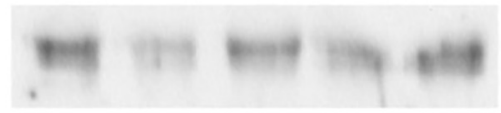

$110 k D a$

WB:bLf
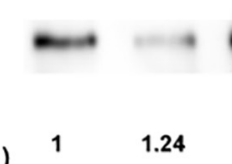

Ratio Pma1p/bLf (relative to BY4741)
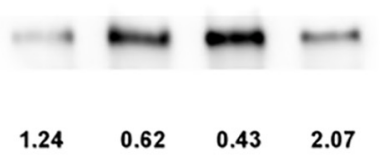

$-85 k D a$

G

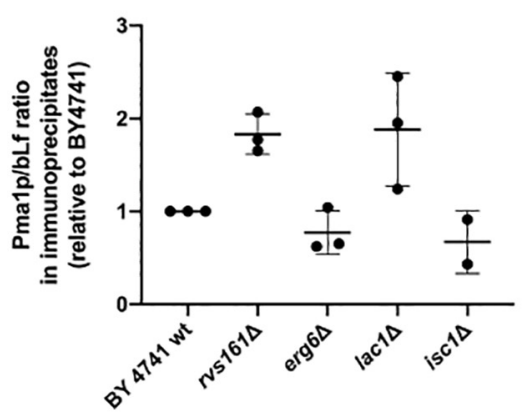

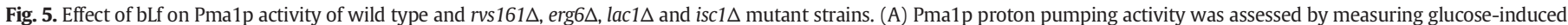

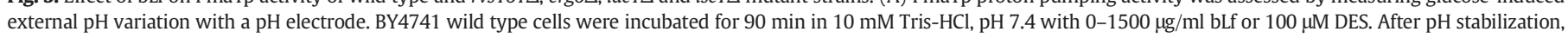

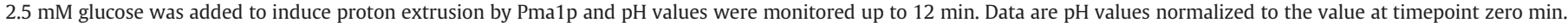

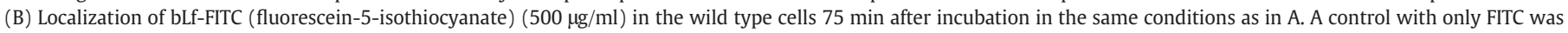

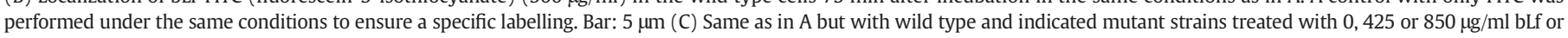

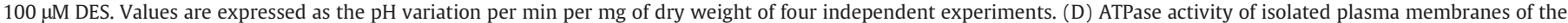

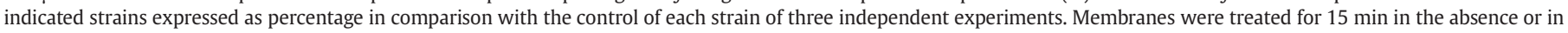

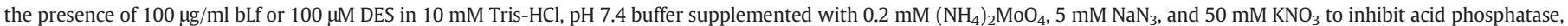

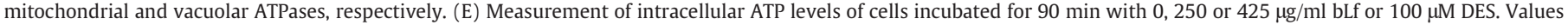

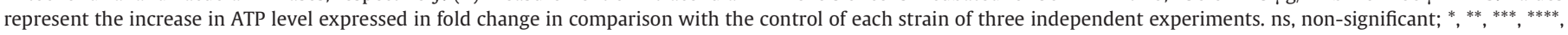

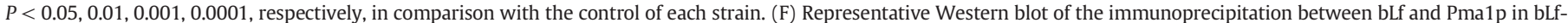

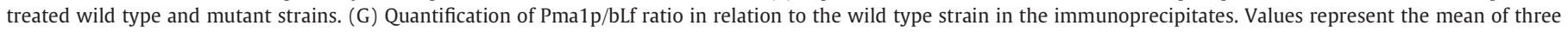
independent experiments. 

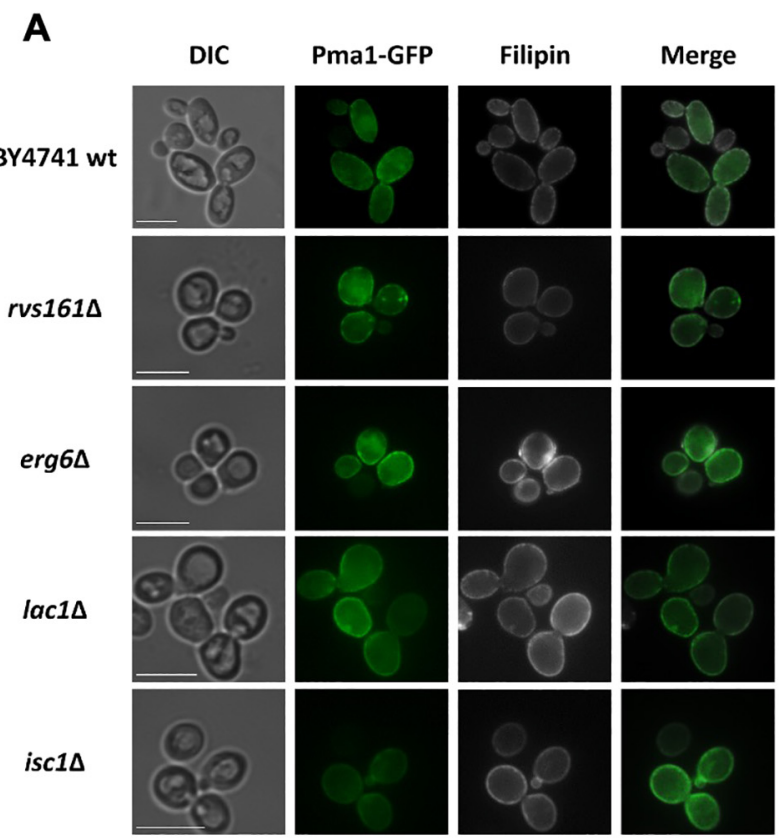

Bar: $7.5 \mu \mathrm{m}$
B

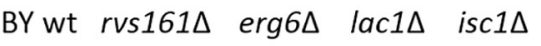

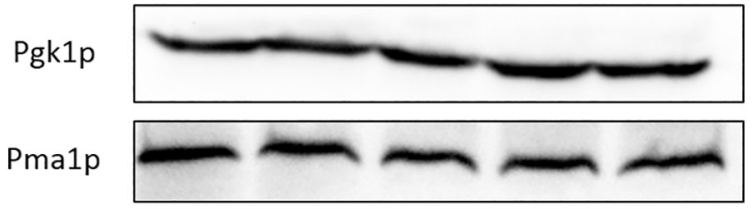

C

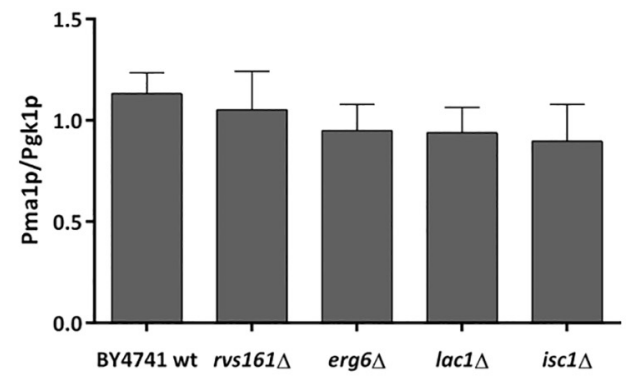

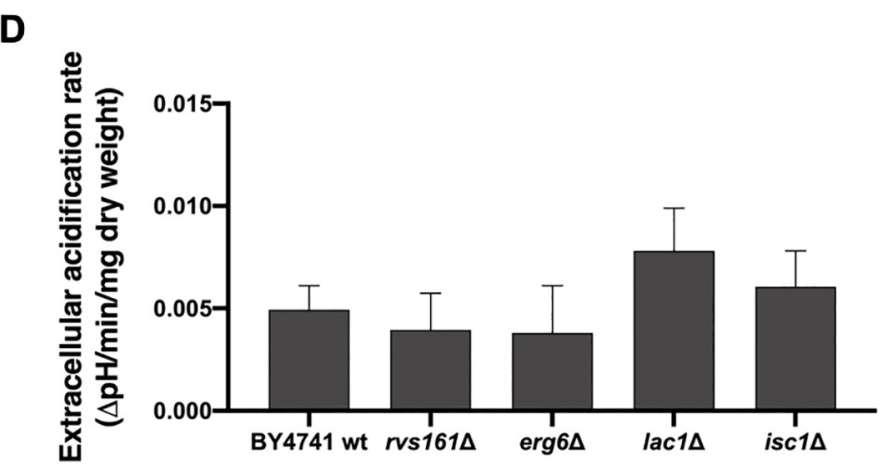

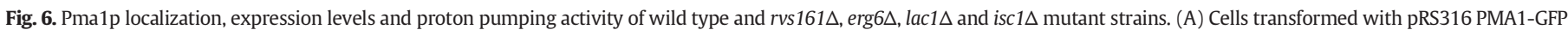

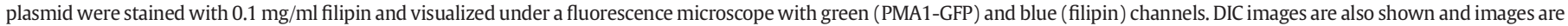

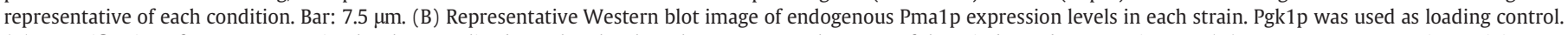

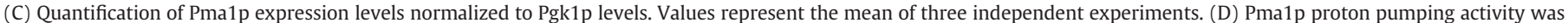

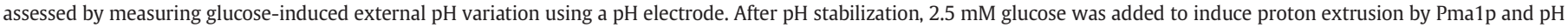

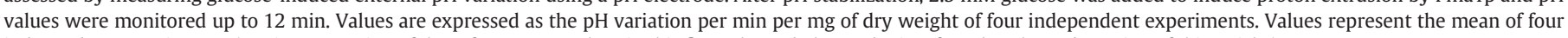
independent experiments. (For interpretation of the references to colour in this figure legend, the reader is referred to the web version of this article.)

was found that edelfosine displaces sterols from the plasma membrane and induces loss of Pma1p from lipid rafts [46]. Mr, Interestingly, the bLf effect on lipid rafts differs from $M \beta C D$, which is known to disrupt lipid rafts by depleting ergosterol from the plasma membrane [37]. Actually, while both compounds led to intracellular accumulation of ergosterol, in contrast to $\mathrm{M} \beta C D$, bLf-treated cells still preserved ergosterol staining at the plasma membrane, as visualized by the intracellular and plasma membrane filipin staining. This suggests that bLf impairs the sorting of newly synthetized ergosterol to the lipid rafts of the cell surface, rather than sequestering it from the plasma membrane.

In order to gain insights on the importance of lipid rafts integrity for bLf antifungal activity, a comprehensive characterization of the phenotype of mutant strains lacking the lipid rafts-associated proteins Rvs161p, Erg6p, Lac1p or Isc1p was performed. Ergosterol plays crucial roles in bulk membrane functions and in lipid rafts formation as it is essential for membrane fluidity/rigidity, permeability and for the protein sorting along the secretory pathway $[47,48]$. In $\operatorname{erg} 6 \Delta$ mutants, the accumulated ergosterol precursors do not allow a tight packing of the lipid bilayer, specifically the lipid acyl chains, and are suggested to create voids in the plasma membrane [47]. Accumulation of ergosterol intermediates can also alter lipid rafts structures, promote missorting of different plasma membrane proteins [49] and modify membrane permeability and fluidity [50]. Sphingolipids are a multifunctional class of lipids critical for lipid rafts formation and for many other functions including the transport of glycosylphosphatidylinositol (GPI)-anchored proteins out of the endoplasmic reticulum, protein sorting and signalling [51]. In yeast, ceramides can be produced either de novo through Lag1p/Lac1p/Lip1p, or from complex sphingolipids hydrolysis through Isc1p [25]. LAC1 and LAG1 are highly homologous and have a similar function; along with a small accessory subunit Lip1p, Lac1p and Lag1p are demonstrated constituents of the ceramide synthase complex [52]. Deletion of both genes influences the levels of ceramides and long chain bases [52,53]. Yeast cells lacking Lac1p show an abnormal low amount of GPI-anchored proteins and impaired capacity to link the ceramide moiety into GPI anchors, which are very important for the association of different proteins to lipid rafts $[53,54]$. In turn, isc $1 \Delta$ cells contain higher amount of complex sphingolipids [55], decreased levels of mitochondrial ceramide and mitochondrial function defects [56]. Another mutant studied herein lacks the Rvs161 protein, a lipid rafts component involved in cytoskeleton organization, cell polarity, endocytosis 
A
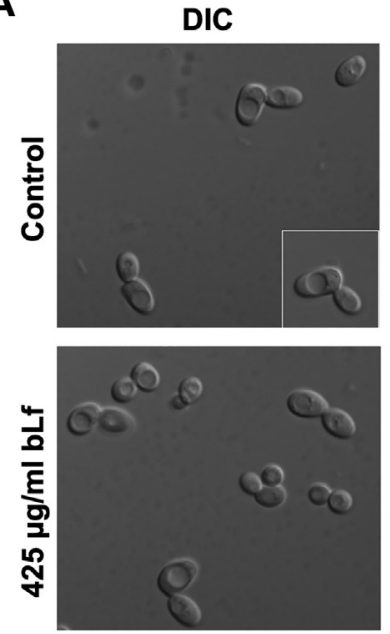

Bar: $7.5 \mu \mathrm{m}$
CDCFDA
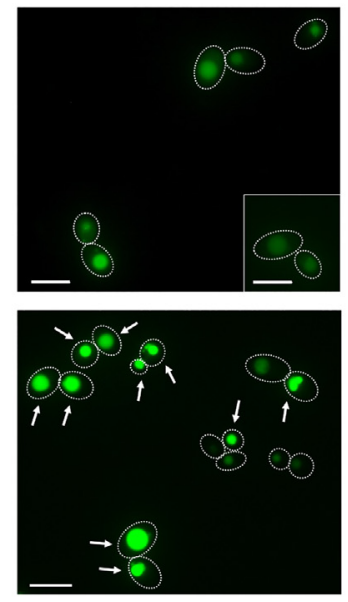

B

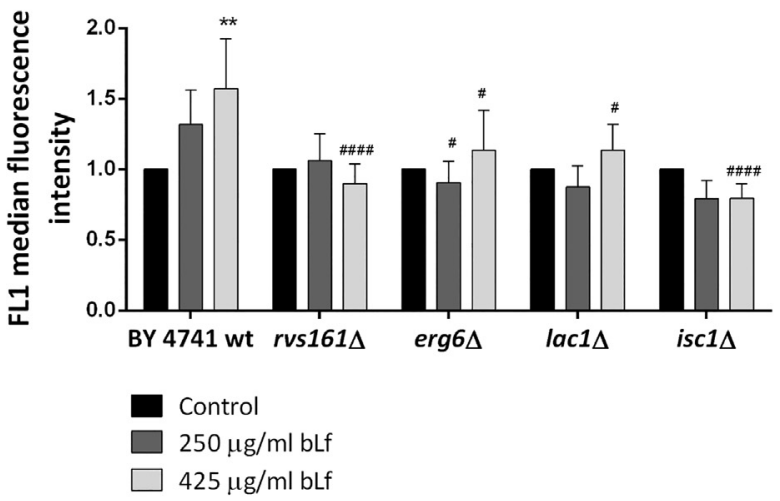

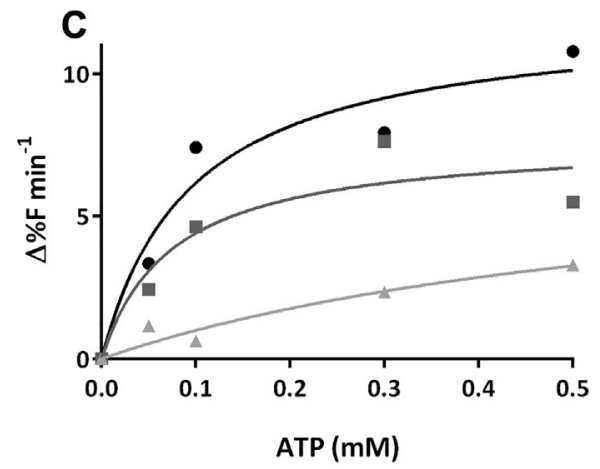

$\rightarrow$ Control $\rightarrow 4 \mu \mathrm{g} / \mathrm{ml} \mathrm{bLf} \leftarrow 80 \mu \mathrm{g} / \mathrm{ml} \mathrm{bLf}$

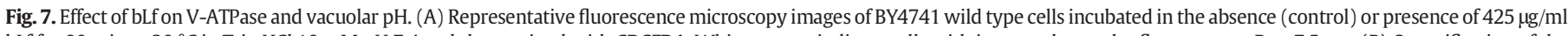

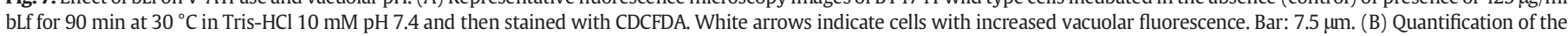

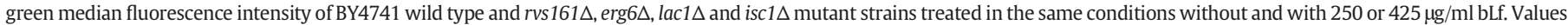

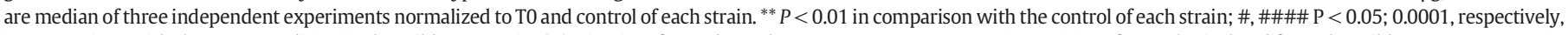

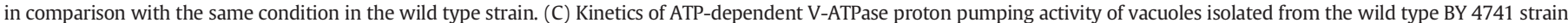

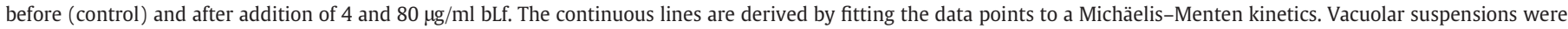

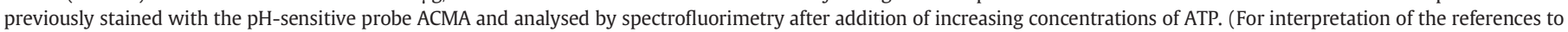
colour in this figure legend, the reader is referred to the web version of this article.)

and in vesicle trafficking [23,57]. Its association with the lipid rafts is thought to be mediated by a putative raft-bound protein as it has no GPI signal anchor or transmembrane domain [23]. We found that cells lacking Rvs161p, Lac1p, Isc1p and Erg6p are more resistant to bLfinduced cell death than the wild type strain and exhibited a lower inhibition of the extracellular acidification rate and Pma1p hydrolytic activity, as well as no enhancement of the intracellular ATP level. Moreover, while $500 \mu \mathrm{g} / \mathrm{ml}$ bLf induced a drastic loss of cell viability in the erg6 $\Delta$ and rvs161 $\Delta$ mutants similarly to the wild type, their metabolic activity was not affected in contrast to the wild type. Indeed, these two mutant strains, as well as isc $1 \Delta$ and lac1 $\Delta$ were still able to process the FUN-1 dye and form CIVS when incubated with $425 \mu \mathrm{g} / \mathrm{ml}$ bLf, which induces a similar percentage of cell viability as $500 \mu \mathrm{g} / \mathrm{ml}$ bLf in the wild type (Fig. 2A). These results suggest that normal levels of ergosterol, sphingolipids and lipid rafts-associated proteins determine the bLf killing activity against yeast but not its effect on metabolic activity.

We hypothesized that changes in Pma1p localization, expression and activity in the mutant strains could explain the reduced cytotoxic effects of bLf in the mutant strains. However, this hypothesis was discarded as Pma1p localization and levels of expression and activity of the mutants were identical to those of the wild type strain. The results regarding the $\operatorname{erg} 6 \Delta$ mutant are in agreement with previous works showing that Pma1p localization at the plasma membrane was intact in different erg mutants [58,59], and that the extracellular medium acidification kinetics in the erg24 $\Delta$ mutant was identical to the wild type strain [60]. Moreover, it was shown that deletion of ISC1 in Cryptococcus neoformans did not affect the synthesis and transport of Pma1p [61], which is in agreement with our data. Unexpectedly, the inhibition of Pma1p activity by bLf was not associated with lack of Pma1p-bLf binding since this was not abrogated in the mutant strains. In addition, bLf was unable to perturb the ergosterol-rich lipid rafts distribution in the mutant strains, indicating that this bLf-induced alteration is also dependent on the normal composition of lipid rafts. Altogether this suggests that the perturbation of lipid rafts is intimately related with Pma1p inhibition, and both effects seem to depend on each other.

Evidence supporting the hypothesis that bLf requires the integrity of Pma1p-lipid rafts association to inhibit Pma1p and induce yeast cell death was provided by the experiments with the strain harbouring Pma1p point mutations and with the ast1 $\Delta$ strain. Pma1-10 mutation renders a defective association of Pma1p with the lipid rafts at $37{ }^{\circ} \mathrm{C}$ 
A

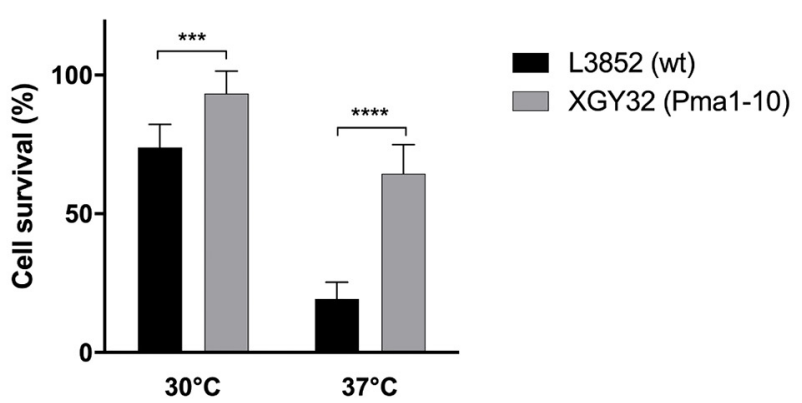

B

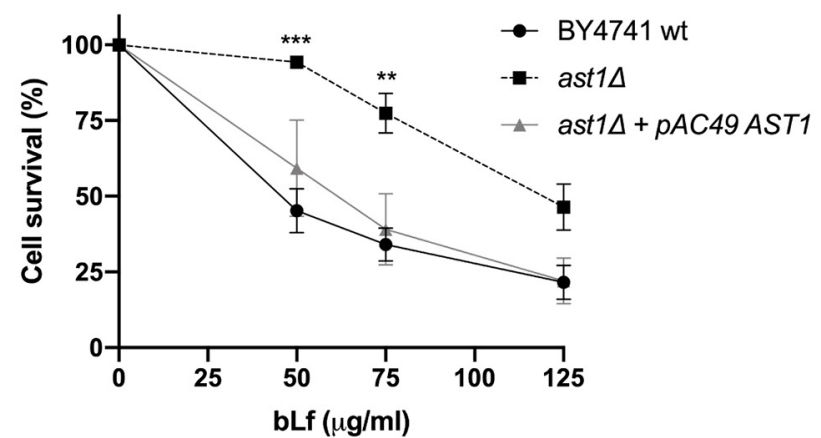

C
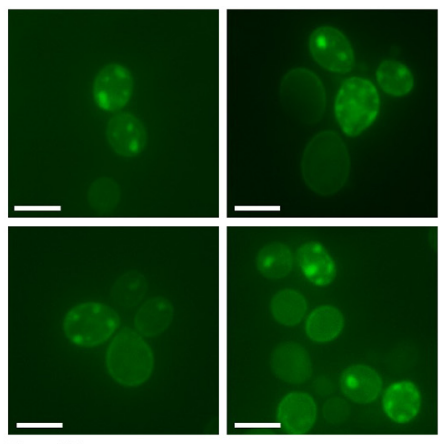

D

E
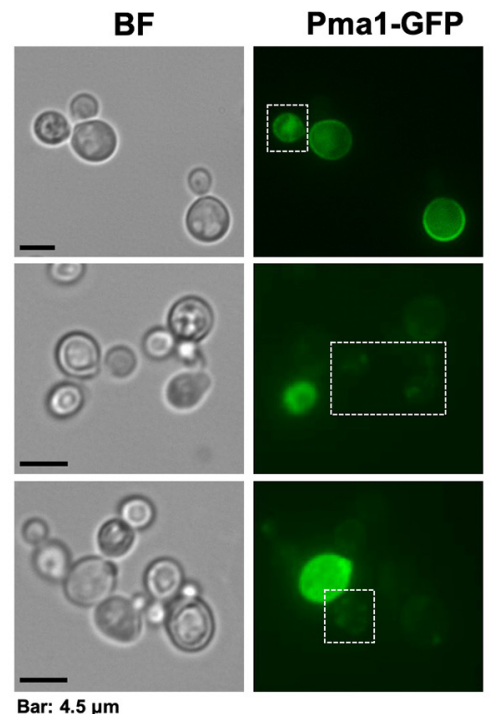

Filipin
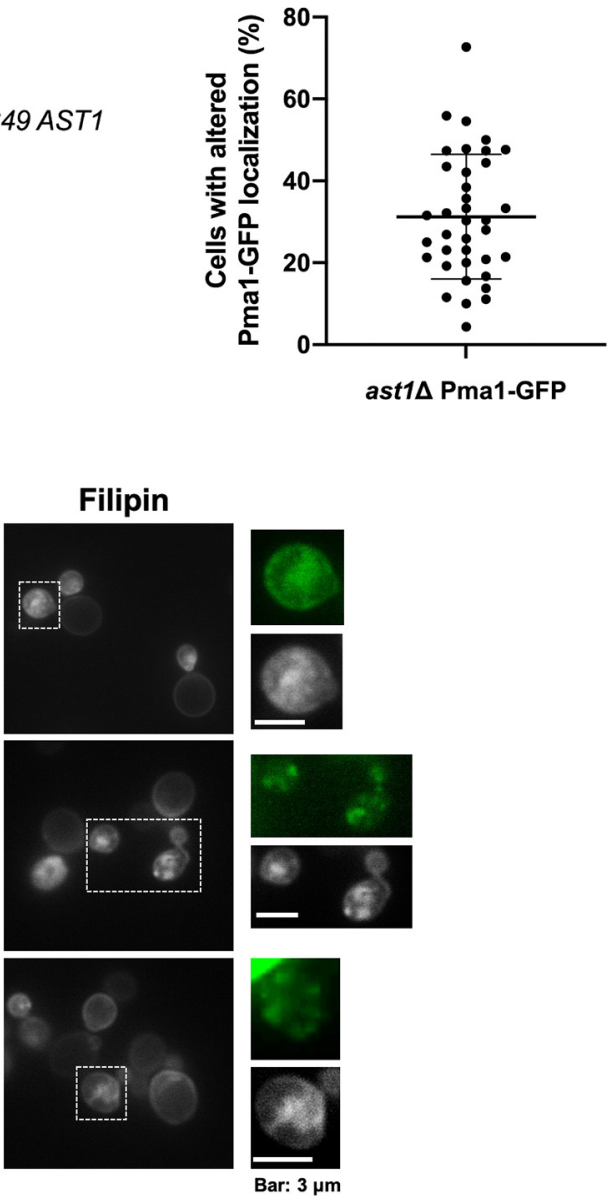

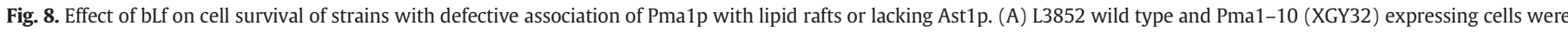

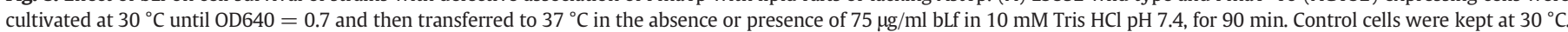

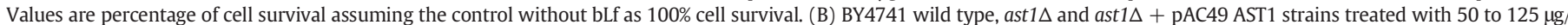

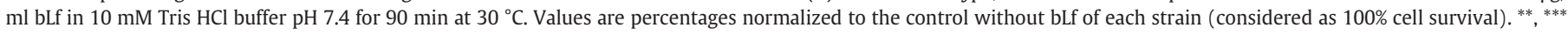

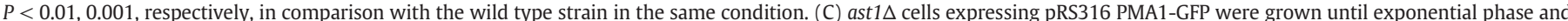

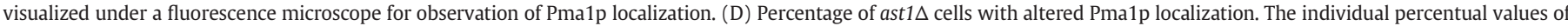

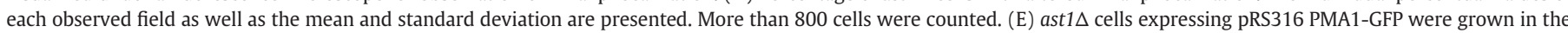

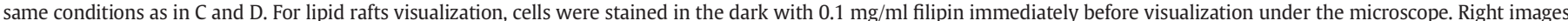
are the zoom in with higher exposure of the indicated sections of the whole images. Bars: $4.5 \mu \mathrm{m}$ or $3 \mu \mathrm{m}$, as indicated in the figure.

[16], temperature at which the strain became much more resistant to bLf than the wild type strain. At a permissive temperature, where Pma1-10 is associated with the lipid rafts, the sensitivity to bLf was similar to the wild type cells. In addition, deletion of the AST1 gene that encodes a protein involved in Pma1p association with the lipid rafts [17], rendered yeast cells resistant to bLf, and its overexpression in the deletion background restored the sensitivity to bLf. The Pma1p and lipid rafts distribution are affected in the ast1 $\Delta$ strain, further supporting that the alteration of Pma1p-lipid rafts association underlies the bLfresistance phenotype of this strain.

Besides being involved in the association of Pma1p with lipid rafts, Ast1p was also demonstrated to induce Pma1p oligomerization, which is an early event during the surface delivery of Pma1p [17]. Pma1p forms large oligomeric complexes of about $1 \mathrm{MDa}$ [18] and this process 
seems to be affected by alterations in the sphingolipids synthesis. Indeed, deletion of ISC1 in C. neoformans perturbed Pma1p oligomerization, which was restored after supplementation with phytoceramide [61]. Depletion of sphingolipids either by using the lcb1-100 strain, which is unable to synthetize sphingolipids, or myriocin, an inhibitor of serine palmitoyltransferase activity, inhibits the oligomerization of newly synthetized Pma1p. Addition of the ceramide precursor phytosphingosine restored Pma1p oligomerization, reinforcing the importance of sphingolipid levels for Pma1p oligomerization [18]. Accordingly, the requirement of sphingolipids for Pma1p oligomerization at the ER, plasma membrane targeting, stability and acquisition of detergent resistance of Pma1p has been reported by different authors $[19,58]$. In agreement with these data, herein we found that exogenous addition of C2-ceramide reverts the resistance phenotype of the lac1 $\Delta$ mutant strain to bLf, likely by counteracting defects in Pma1p oligomerization as a result of sphingolipids composition reestablishment (Fig. S1). Hence, the most likely explanation for the mutant's resistance phenotypes is that alterations in the lipidic content of cells, namely unbalanced ceramide/complex sphingolipids ratio, accumulation of ergosterol precursors, or the abnormal production of GPI anchors modifies the composition of plasma membrane lipid rafts, affecting Pma1p conformation and oligomerization, and consequently its inhibition by bLf. Accordingly, it has been suggested that perturbation of the lipid rafts functional organization creates a different biophysical environment that may change the conformation of raft-localized proteins, including Pma1p [62].
Another novelty of the present study regards the inhibition of the VATPase by bLf. The observed inhibition of this proton pump in purified vacuoles from the wild type strain correlated well with the observed increase of the vacuolar $\mathrm{pH}$ in whole cells in response to bLf. As for the strains with altered lipid rafts composition, the vacuolar $\mathrm{pH}$ was not affected most likely due to the inability of bLf to inhibit Pma1p and cause intracellular acidification. Nonetheless, a possible alteration of the vacuolar membrane lipid composition may also account for the apparent incapacity of bLf to inhibit V-ATPase in these strains. These results are in accordance with our previous data showing that bLf increases the lysosomal pH of highly metastatic cancer cells [42] and inhibits the activity of the V-ATPase that is targeted to the plasma membrane of highly metastatic cancer cells, as well as the activity of purified rat liver lysosomes V-ATPase [35].

\section{Conclusion}

The results gathered in this study demonstrate that the mode of action underlying bLf antifungal activity lies on the perturbation of lipid rafts organization and inhibition of Pma1p activity, and likely of VATPase activity, as suggested by our data with whole cells and isolated vacuoles (Fig. 9). Moreover, the composition of the plasma membrane lipid rafts, Pma1p oligomerization status, as well as the integrity of Ast1p-mediated lipid rafts-Pma1p association seems to be crucial for the interaction of bLf with Pma1p, and for its killing activity against S. cerevisiae. We propose that this novel bLf lipid rafts disrupting activity

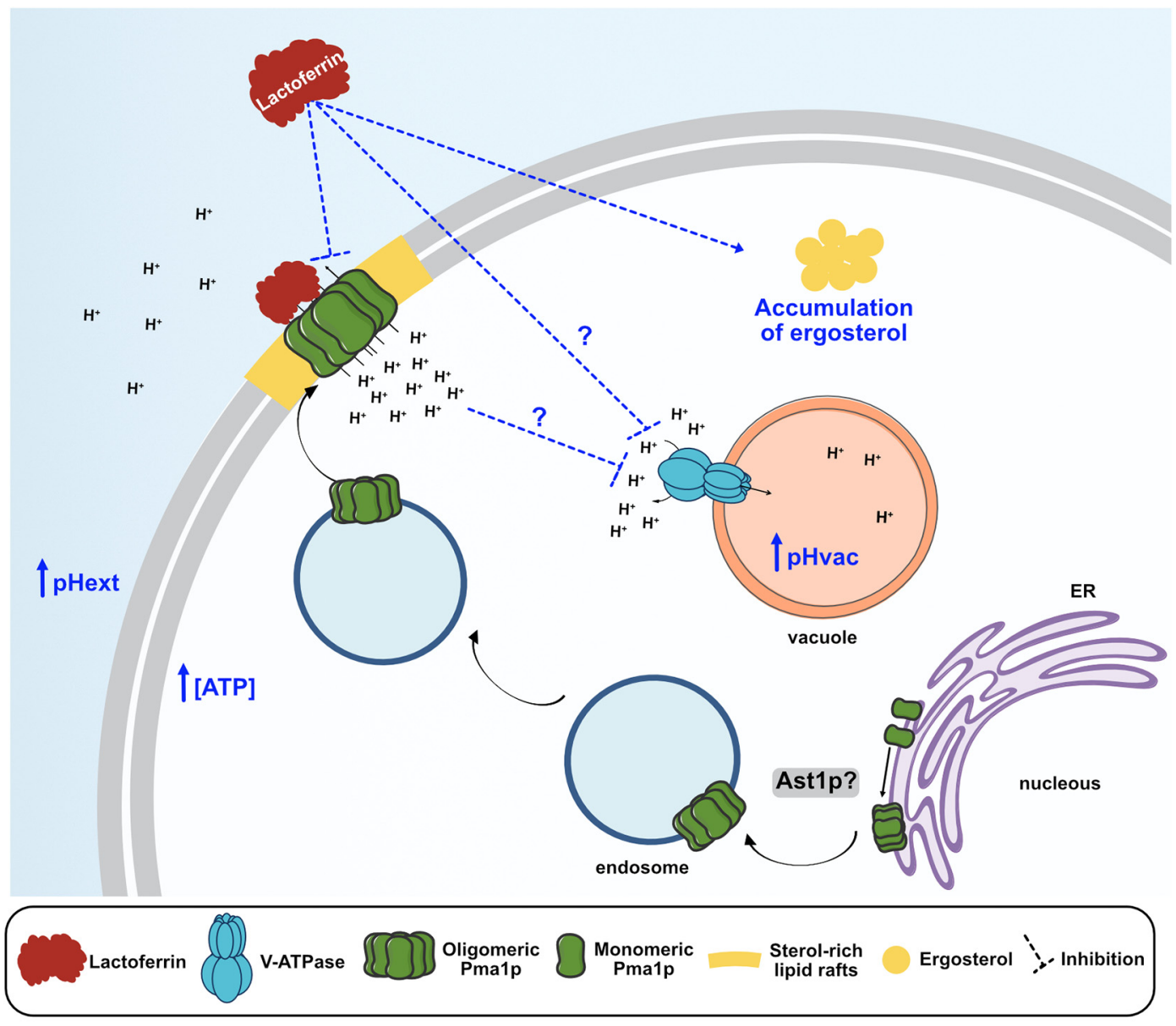

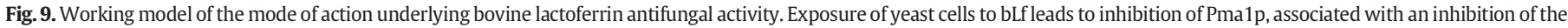

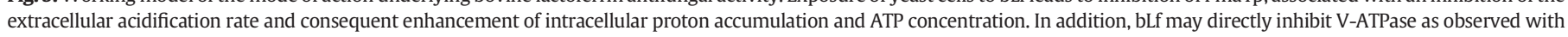

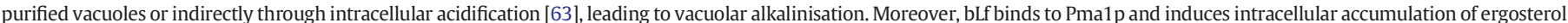

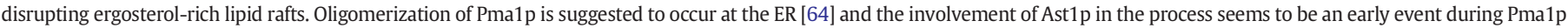

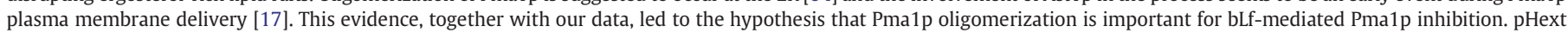
(extracelular $\mathrm{pH}$ ), pHvac (vacuolar $\mathrm{pH}$ ), ER (endoplasmic reticulum). 
may be explored towards antifungal therapy alone or in combination with classical antifungals.

\section{Funding}

This work was supported by national funds through the Portuguese Foundation for Science and Technology (FCT I.P.) under the scope of the strategic funding of "Contrato-Programa" UIDB/04050/2020 and UIDB/ 04469/2020 unit; by the BioTecNorte operation (NORTE-01-0145FEDER-000004) funded by the European Regional Development Fund under the scope of Norte2020 - Programa Operacional Regional do Norte; and by the Servicio para el Control de la Esterilización, Laboratorio de Microbiología Oral (CN-16-036). Cátia Santos-Pereira acknowledges the PhD fellowship PD/BD/128032/2016 funded by FCT under the scope of the doctoral programme in Applied and Environmental Microbiology (DP_AEM).

\section{CRediT authorship contribution statement}

Cátia Santos Pereira: Conceptualization, Data curation, Formal analysis, Investigation, Validation, Visualization, Writing - original draft, Writing - review \& editing; María T. Andrés: Data curation, Formal analysis, Investigation, Validation, Writing - review \& editing; Susana R. Chaves: Investigation, Validation, Writing - review \& editing; José F. Fierro: Funding acquisition, Investigation, Resources, Supervision, Validation, Writing - review \& editing; Hernâni Gerós: Resources, Validation, Writing - review \& editing; Stéphen Manon: Data curation, Formal analysis, Investigation, Resources, Funding acquisition, Supervision, Validation, Visualization, Writing - review \& editing; Lígia R. Rodrigues and Manuela Côrte-Real: Conceptualization, Data curation, Funding acquisition, Project administration, Resources, Supervision, Validation, Writing - original draft, Writing - review \& editing.

\section{Declaration of competing interest}

The authors declare no competing interests.

\section{Acknowledgements}

The authors thank Dr. Shingo Izawa and Dr. Annick Breton for the pRS316 Pma1-GFP plasmid, Dr. Amy Chang for the L3852 and XGY32 strains as well as the pAC49 AST1 plasmid, and Dr. Paula Ludovico and Dr. Belém Sampaio-Marques for the ast $1 \Delta$ strain.

\section{Appendix A. Supplementary data}

Supplementary data to this article can be found online at https://doi. org/10.1016/j.ijbiomac.2020.12.224.

\section{References}

[1] L. Hao, Q. Shan, J. Wei, F. Ma, P. Sun, Lactoferrin: major physiological functions and applications, Curr. Protein Pept. Sci. 20 (2019) 139-144, https://doi.org/10.2174/ 1389203719666180514150921

[2] M. Sorensen, S. Sorensen, The proteins in whey, Compte Rendu Des Trav. Du Lab. Carlsb. 23 (1939) 55-99.

[3] L. Moreno-Expósito, R. Illescas-Montes, L. Melguizo-Rodríguez, C. Ruiz, J. RamosTorrecillas, E. de Luna-Bertos, Multifunctional capacity and therapeutic potential of lactoferrin, Life Sci. 195 (2018) 61-64, https://doi.org/10.1016/j.lfs.2018.01.002.

[4] K.E. Fernandes, D.A. Carter, The antifungal activity of lactoferrin and its derived peptides: mechanisms of action and synergy with drugs against fungal pathogens, Front. Microbiol. 8 (2017) 1-10, https://doi.org/10.3389/fmicb.2017.00002.

[5] M.T. Andrés, M. Viejo-Díaz, J.F. Fierro, Human lactoferrin induces apoptosis-like cell death in Candida albicans: critical role of $\mathrm{K}+$-channel-mediated $\mathrm{K}+$ efflux, Antimicrob. Agents Chemother. 52 (2008) 4081-4088, https://doi.org/10.1128/ AAC.01597-07.

[6] M. Acosta-Zaldívar, M.T. Andrés, A. Rego, C.S. Pereira, J.F. Fierro, M. Côrte-Real, Human lactoferrin triggers a mitochondrial- and caspase-dependent regulated cell death in Saccharomyces cerevisiae, Apoptosis. 21 (2016) 163-173, https://doi.org/ 10.1007/s10495-015-1199-9.

[7] M.T. Andrés, M. Acosta-Zaldívar, J.F. Fierro, Antifungal mechanism of action of lactoferrin: identification of $\mathrm{H}+$-ATPase (P3A-type) as a new apoptotic-cell membrane receptor, Antimicrob. Agents Chemother. 60 (2016) 4206-4216, https://doi org/10.1128/AAC.03130-15.

[8] P. Kane, Proton transport and pH control in Fungi, Adv. Exp. Med. Biol. 892 (2016) 33-68, https://doi.org/10.1007/978-3-319-25304-6.

[9] M.T. Andrés, M. Acosta-Zaldívar, J. González-Seisdedos, J.F. Fierro, Cytosolic acidification is the first transduction signal of lactoferrin-induced regulated cell death pathway, Int. J. Mol. Sci. 20 (2019) 5838, https://doi.org/10.3390/ijms20235838.

[10] M. Bagnat, S. Keränen, A. Shevchenko, A. Shevchenko, K. Simons, Lipid rafts function in biosynthetic delivery of proteins to the cell surface in yeast, Proc. Natl. Acad. Sci. U. S. A. 97 (2000) 3254-3259, https://doi.org/10.1073/pnas.97.7.3254.

[11] F. Mollinedo, Lipid raft involvement in yeast cell growth and death, Front. Oncol. 2 (2012) 1-15, https://doi.org/10.3389/fonc.2012.00140.

[13] M. Kodedová, M. Valachovič, Z. Csáky, H. Sychrová, Variations in yeast plasmamembrane lipid composition affect killing activity of three families of insect antifungal peptides, Cell. Microbiol. 21 (2019)https://doi.org/10.1111/cmi.13093.

[14] R. Pasrija, T. Prasad, R. Prasad, Membrane raft lipid constituents affect drug susceptibilities of Candida albicans, Biochem. Soc. Trans. 33 (2005) 1219-1223, https://doi org/10.1042/BST20051219.

[15] M. Rautenbach, A.M. Troskie, J.A. Vosloo, Antifungal peptides: to be or not to be membrane active, Biochimie. 130 (2016) 132-145, https://doi.org/10.1016/j. biochi.2016.05.013.

[16] X. Gong, A. Chang, A mutant plasma membrane ATPase, Pma1-10, is defective in stability at the yeast cell surface, Proc. Natl. Acad. Sci. 98 (2001) 9104-9109, https:// doi.org/10.1073/pnas.161282998.

[17] M. Bagnat, A. Chang, K. Simons, Plasma membrane proton ATPase Pma1p requires raft Association for Surface Delivery in yeast, Mol. Biol. Cell 12 (2001) 4129-4138, https://doi.org/10.1091/mbc.12.12.4129.

[18] M.C.S. Lee, S. Hamamoto, R. Schekman, Ceramide biosynthesis is required for the formation of the oligomeric $\mathrm{H}+$-ATPase Pma1p in the yeast endoplasmic reticulum, J. Biol. Chem. 277 (2002) 22395-22401, https://doi.org/10.1074/jbc.M200450200.

[19] Q. Wang, A. Chang, Sphingoid base synthesis is required for oligomerization and cell surface stability of the yeast plasma membrane ATPase, Pma1, Proc. Natl. Acad. Sci. U. S. A. 99 (2002) 12853-12858, https://doi.org/10.1073/pnas.202115499.

[20] A. Pierce, D. Colavizza, M. Benaissa, P. Maes, A. Tartar, J. Montreuil, G. Spik, Molecular cloning and sequence analysis of bovine lactotransferrin, Eur. J. Biochem. 196 (1991) 177-184, https://doi.org/10.1111/j.1432-1033.1991.tb15801.x.

[21] J.M. Steijns, A.C.M. van Hooijdonk, Occurrence, structure, biochemical properties and technological characteristics of lactoferrin, Br. J. Nutr. 84 (2000) 11-17, https://doi.org/10.1017/s0007114500002191.

[22] M.E. Kuipers, H.G. De Vries, M.C. Eikelboom, D.K.F. Meijer, P.J. Swart, Synergistic fungistatic effects of lactoferrin in combination with antifungal drugs against clinical Candida isolates, Antimicrob. Agents Chemother. 43 (1999) 2635-2641, https:// doi.org/10.1128/aac.43.11.2635.

[23] A. Balguerie, M. Bagnat, M. Bonneu, M. Aigle, A.M. Breton, Rvs161p and sphingolipids are required for actin repolarization following salt stress, Eukaryot Cell 1 (2002) 1021-1031, https://doi.org/10.1128/EC.1.6.1021-1031.2002.

[24] A.L. Munn, A. Heese-Peck, B.J. Stevenson, H. Pichler, H. Riezman, Specific sterols required for the internalization step of endocytosis in yeast, Mol. Biol. Cell 10 (1999) 3943-3957, https://doi.org/10.1091/mbc.10.11.3943.

[25] L. Cowart, L.M. Obeid, Yeast sphingolipids: recent developments in understanding biosynthesis, Biochim. Biophys. Acta 1771 (2007) 233-245, https://doi.org/10. 1016/j.dcn.2011.01.002.The.

[26] R.D. Gietz, R.A. Woods, Yeast transformation by the LiAc/SS Carrier DNA/PEG method, Methods Mol. Biol. - Yeast Protoc, Second ed. 2006, pp. 107-120, https:// doi.org/10.1385/1-59259-958-3:107.

[27] F.R. Maxfield, D. Wüstner, Analysis of cholesterol trafficking with fluorescent probes, Methods Cell Biol. 108 (2012) 367-393, https://doi.org/10.1016/B978-0-12386487-1.00017-1.

[28] A. Pacheco, F. Azevedo, A. Rego, J. Santos, S.R. Chaves, M. Côrte-Real, M.J. Sousa, C2phytoceramide perturbs lipid rafts and cell integrity in Saccharomyces cerevisiae in a sterol-dependent manner, PLoS One 8 (2013) 1-12, https://doi.org/10.1371/journal. pone.0074240.

[29] P. Millard, B. Roth, H.-G. Thi, S. Yue, R. Haugland, Development of the FUN-1 family of fluorescent probes for vacuole labeling and viability testing of yeasts, Appl. Environ. Microbiol. 63 (1997) 2897-2905.

[30] M.M. Bradford, A rapid and sensitive method for the quantitation of microgram quantities of protein utilizing the principle of protein-dye binding, Anal. Biochem. 72 (1976) 248-254.

[31] B.C. Monk, M.B. Kurtz, J.A. Marrinan, D.S. Perlin, Cloning and characterization of the plasma membrane H+-ATPase from Candida albicans, J. Bacteriol. 173 (1991) 6826-6836, https://doi.org/10.1128/jb.173.21.6826-6836.1991.

[32] J.M.P. Rodrigues, C.S. Pereira, N. Fontes, H. Gerós, M. Côrte-Real, Flow cytometry and fluorescence microscopy as tools from yeast and plant cells, Plant Vacuolar Traffick. Methods Protoc. 1789 (2018) 101-115, https://doi.org/10.1007/978-1-4939-78564 4.8.

[33] J. Rodrigues, R.D. Silva, H. Noronha, A. Pedras, H. Gerós, M. Côrte-Real, Flow cytometry as a novel tool for structural and functional characterization of isolated yeast vacuoles, Microbiology. 159 (2013) 848-856, https://doi.org/10.1099/mic.0. 062570-0.

[34] O.H. Lowry, N.J. Rosebrough, L. Farr, R.J. Randall, Protein measurement with the folin phenol reagent, J. Biol. Chem. 193 (1951). 
[35] C.S. Pereira, J.P. Guedes, M. Gonçalves, L. Loureiro, L. Castro, H. Gerós, L.R. Rodrigues, M. Côrte-Real, Lactoferrin selectively triggers apoptosis in highly metastatic breast cancer cells through inhibition of plasmalemmal V-H+-ATPase, Oncotarget 7 (2016) 62144-62158, https://doi.org/10.18632/oncotarget.11394.

[36] M.C. Teixeira, L.R. Raposo, N.P. Mira, A.B. Lourenço, I. Sá-Correia, Genome-wide identification of Saccharomyces cerevisiae genes required for maximal tolerance to ethanol, Appl. Environ. Microbiol. 75 (2009) 5761-5772, https://doi.org/10.1128/AEM. 00845-09.

[37] A.R. Siafakas, L.C. Wright, T.C. Sorrell, J.T. Djordjevic, Lipid rafts in Cryptococcus neoformans concentrate the virulence determinants phospholipase $\mathrm{B} 1 \mathrm{and} \mathrm{cu} / \mathrm{Zn}$ superoxide dismutase, Eukaryot. Cell 5 (2006) 488-498, https://doi.org/10.1128/EC.5. 3.488-498.2006.

[38] M.D. Eggleston, P.A. Marshall, Saccharomyces cerevisiae samples stained with FUN-1 dye can be stored at $-20^{\circ} \mathrm{C}$ for later observation, J. Microsc. 225 (2007) 100-103, https://doi.org/10.1111/j.1365-2818.2007.01720.x.

[39] C. Prudêncio, F. Sansonetty, M. Côrte-Real, Flow cytometric assessment of cell structural and functional changes induced by acetic acid in the yeasts Zygosaccharomyces bailii and Saccharomyces cerevisiae, Cytometry. 31 (1998) 307-313, https://doi.org/ 10.1002/(SICI)1097-0320(19980401)31:4<307::AID-CYTO11>3.0.CO;2-U.

[40] G. Grossmann, J. Malinsky, W. Stahlschmidt, M. Loibl, I. Weig-Meckl, W.B. Frommer, M. Opekarová, W. Tanner, Plasma membrane microdomains regulate turnover of transport proteins in yeast, J. Cell Biol. 183 (2008) 1075-1088, https://doi.org/10. 1083/jcb.200806035.

[41] C. Roberts, C. Raymond, C. Yamashiro, T.H. Stevens, Methods for studying the yeast vacuole, Methods Enzymol. 194 (1991) 644-661.

[42] J. Guedes, C. Pereira, L. Rodrigues, M. Côrte-real, Bovine milk lactoferrin selectively kills highly metastatic prostate cancer PC-3 and osteosarcoma MG-63 cells in vitro, Front. Oncol. 8 (2018) 1-12, https://doi.org/10.3389/fonc.2018.00200.

[43] A. Chang, G.R. Fink, Targeting of the yeast plasma membrane [H+]ATPase: a novel gene AST1 prevents mislocalization of mutant ATPase to the vacuole, J. Cell Biol. 128 (1995) 39-49, https://doi.org/10.1083/jcb.128.1.39.

[44] K.E. Fernandes, K. Weeks, D.A. Carter, Lactoferrin is broadly active against yeasts and highly synergistic with amphotericin B, Antimicrob. Agents Chemother. 64 (2020) 1-22, https://doi.org/10.1128/AAC.02284-19.

[45] E. Lahoz, A. Pisacane, M. Iannaccone, D. Palumbo, R. Capparelli, Fungistatic activity of iron-free bovin lactoferrin against several fungal plant pathogens and antagonists, Nat. Prod. Res. 22 (2008) 955-961, https://doi.org/10.1080/14786410701650253.

[46] V. Zaremberg, C. Gajate, L.M. Cacharro, F. Mollinedo, C.R. McMaster, Cytotoxicity of an anti-cancer lysophospholipid through selective modification of lipid raft composition, J. Biol. Chem. 280 (2005) 38047-38058, https://doi.org/10.1074/jbc. M502849200.

[47] F. Abe, T. Hiraki, Mechanistic role of ergosterol in membrane rigidity and cycloheximide resistance in Saccharomyces cerevisiae, Biochim. Biophys. Acta Biomembr. 1788 (2009) 743-752, https://doi.org/10.1016/j.bbamem.2008.12.002.

[48] K. Umebayashi, A. Nakano, Ergosterol is required for targeting of tryptophan permease to the yeast plasma membrane, J. Cell Biol. 161 (2003) 1117-1131, https://doi. org/10.1083/jcb.200303088.

[49] K. Daicho, N. Makino, T. Hiraki, M. Ueno, M. Uritani, F. Abe, T. Ushimaru, Sorting defects of the tryptophan permease Tat2 in an erg2 yeast mutant, FEMS Microbiol. Lett. 298 (2009) 218-227, https://doi.org/10.1111/j.1574-6968.2009.01722.x.

[50] R.F. Gaber, D.M. Copple, B.K. Kennedy, M. Vidal, M. Bard, The yeast gene ERG6 is required for normal membrane function but is not essential for biosynthesis of the cell-cycle-sparking sterol, Mol. Cell. Biol. 9 (1989) 3447-3456, https://doi.org/10 1128/MCB.9.8.3447.

[51] F. Martinez-Montanes, M.A. Lone, F.F. Hsu, R. Schneiter, Accumulation of long-chain bases in yeast promotes their conversion to a long-chain base vinyl ether, J. Lipid Res. 57 (2016) 2040-2050, https://doi.org/10.1080/00140139108967302.

[52] S. Schorling, B. Vallée, W.P. Barz, H. Riezman, D. Oesterhelt, Lag1p and Lac1p are essential for the acyl-CoA-dependent ceramide synthase reaction in Saccharomyces cerevisae, Mol. Biol. Cell 12 (2001) 3417-3427, https://doi.org/10.1091/mbc.12.11. 3417.

[53] I. Guillas, P.A. Kirchman, R. Chuard, M. Pfefferli, J.C. Jiang, S.M. Jazwinski, A. Conzelmann, C26-CoA-dependent ceramide synthesis of Saccharomyces cerevisiae is operated by Lag1p and Lac1p, EMBO J. 20 (2001) 2655-2665, https://doi.org/10. 1093/emboj/20.11.2655.

[54] T. Kinoshita, M. Fujita, Biosynthesis of GPI-anchored proteins: special emphasis on GPI lipid remodeling, J. Lipid Res. 57 (2016) 6-24, https://doi.org/10.1194/jlr. R063313.

[55] H. Sawai, Y. Okamoto, C. Luberto, C. Mao, A. Bielawska, N. Domae, Y.A. Hannun, Identification of ISC1 (YERO19w) as inositol phosphosphingolipid phospholipase C in Saccharomyces cerevisiae, J. Biol. Chem. 275 (2000) 39793-39798, https://doi.org/ 10.1074/jbc.M007721200.

[56] H. Kitagaki, L.A. Cowart, N. Matmati, S. Vaena de Avalos, S.A. Novgorodov, Y.H Zeidan, J. Bielawski, L.M. Obeid, Y.A. Hannun, Isc1 regulates sphingolipid metabolism in yeast mitochondria, Biochim. Biophys. Acta Biomembr. 1768 (2007) 2849-2861, https://doi.org/10.1016/j.bbamem.2007.07.019.

[57] A.M. Breton, J. Schaeffer, M. Aigle, The yeast Rvs161 and Rvs167 proteins are involved in secretory vesicles targeting the plasma membrane and in cell integrity, Yeast. 18 (2001) 1053-1068, https://doi.org/10.1002/yea.755.

[58] B. Gaigg, B. Timischl, L. Corbino, R. Schneiter, Synthesis of sphingolipids with very long chain fatty acids but not ergosterol is required for routing of newly synthesized plasma membrane ATPase to the cell surface of yeast, J. Biol. Chem. 280 (2005) 22515-22522, https://doi.org/10.1074/jbc.M413472200.

[59] A.F. Estrada, G. Muruganandam, C. Prescianotto-Baschong, A. Spang, The ArfGAP2/3 Glo3 and ergosterol collaborate in transport of a subset of cargoes, Biol. Open. 4 (2015) 792-802, https://doi.org/10.1242/bio.011528.

[60] Y.Q. Zhang, S. Gamarra, G. Garcia-Effron, S. Park, D.S. Perlin, R. Rao, Requirement for ergosterol in V-ATPase function underlies antifungal activity of azole drugs, PLoS Pathog. 6 (2010), e1000939, https://doi.org/10.1371/journal.ppat.1000939.

[61] A.M. Farnoud, V. Mor, A. Singh, M. Del Poeta, Inositol phosphosphingolipid phospholipase C1 regulates plasma membrane ATPase (Pma1) stability in Cryptococcus neoformans, FEBS Lett. 588 (2014) 3932-3938, https://doi.org/10.1016/j.febslet. 2014.09.005.

[62] J. Pan, C. Hu, J.H. Yu, Lipid biosynthesis as an antifungal target, J. Fungi. 4 (2018) 1-13, https://doi.org/10.3390/jof4020050.

[63] R. Dechant, M. Binda, S.S. Lee, S. Pelet, J. Winderickx, M. Peter, Cytosolic pH is a second messenger for glucose and regulates the PKA pathway through V-ATPase, EMBO J. 29 (2010) 2515-2526, https://doi.org/10.1038/emboj.2010.138.

[64] A. Toulmay, R. Schneiter, Lipid-dependent surface transport of the proton pumping ATPase: a model to study plasma membrane biogenesis in yeast, Biochimie. 89 (2007) 249-254, https://doi.org/10.1016/j.biochi.2006.07.020.

[65] A. Rella, A. Farnoud M., M. Del Poeta, Plasma membrane lipids and their role in fungal virulence, Prog. Lipid Res. 61 (2016) 63-72, https://doi.org/10.1016/j.plipres. 2015.11.003. 